\title{
Financial Contagion on the International Trade Network ${ }^{1}$
}

\author{
Raja Kali Javier Reyes ${ }^{2}$ \\ Department of Economics \\ Sam M. Walton College of Business \\ University of Arkansas \\ Fayetteville, AR 72701
}

JEL Classification: F10, F36, F40, G15

Keywords: international trade, network, stock markets, financial contagion

First Version: August 12, 2005

This Version: October 252005

\footnotetext{
${ }^{1}$ We are grateful to Jon Johnson, Fabio Mendez and Anand Swamy for helpful discussions. We thank seminar participants at Harvard Business School, the University of Arkansas, Williams College and MWIEG Fall 2005 for their comments. Viktoria Riiman provided outstanding reseach assistance.

${ }^{2}$ E-mail: rkali@walton.uark.edu, jreyes@walton.uark.edu
} 


\begin{abstract}
We combine data on international trade linkages with a network approach to map the global trading system as an interdependent complex network. This enables us to obtain indicators of how well connected a country is into the global trading system. We use these network-based measures of connectedness to explain stock market returns during recent episodes of financial crisis. We find that a crisis is amplified if the epicenter country is better integrated into the trade network. However, target countries affected by such a shock are in turn better able to dissipate the impact if they are well integrated into the network. A network approach can help explain why the Mexican, Asian and Russian financial crises were highly contagious, while the crises that originated in Venezuela and Argentina did not have such a virulent effect. We suggest that a network approach incorporating the cascading and diffusion of interdependent ripples when a shock hits a specific part of the global trade network provides us with an improved explanation of financial contagion.
\end{abstract}




\section{Introduction}

Does integration into the international trade network make a country more vulnerable to financial crises? A priori, the answer to this question is not obvious. On the one hand, if a country has many distinct trading partners, then there are many pathways through which a shock originating somewhere else can reach it. On the other hand, if a country is hit by an adverse shock, then having many trading partners provides more channels to diversify away the impact. Participation in international trade can thus amplify or cushion the impact of an adverse shock to a country's financial markets. In this paper we attempt to answer this question through a new approach that links the transmission of financial crises to the network of international trade relationships. We suggest that a network approach capable of incorporating the cascading and diffusion of interdependent ripples that happens when a shock hits a specific part of the global trade network provides us with an improved explanation of financial contagion.

Understanding such mechanisms is important given the dramatic increase in international economic integration or "globalization" that has characterized the last decade, together with the increase in the volatility of country-level performance, reflected in several recent episodes of economic and financial crises ${ }^{1}$. One striking characteristic of many of these crises is how an initial country-specific event was rapidly transmitted to markets around the globe. These events sparked the widespread use of a new meaning for the term "contagion" and a surge of interest in the determinants of a country's vulnerability to crises that originate elsewhere in the world. But despite this interest, there continues to be little agreement on why many of these crises that began in relatively small economies had such global repercussions and why shocks originating in one economy affected some markets, while markets in other countries were relatively unaffected.

Part of the problem may be the focus on bilateral trade and finance relationships as channels for transmission. Recent advances in the study of networks (Albert and Barabasi, 2002; Newman, 2003) have placed elegant and powerful tools at our disposal, enabling us to turn from a focus on bilateral relationships to a consideration of the pattern of linkages

\footnotetext{
${ }^{1}$ Prominent examples and their colorful sobriquets are the Mexican "Tequila crisis" of 1994, the "Asian Flu" of 1997, and the "Russian Virus" of 1998.
} 
that tie countries around the world together as a whole. Our first step is thus to combine a network approach with data on international trade linkages in order to map the global trading system as an interdependent complex network ${ }^{2}$, with the countries as nodes and trade relationships as links between them. Countries tied through trade are concurrently linked through credit arrangements as well as pure financial flows. In this spirit, we take the network of international trade linkages to be the backbone that underpins and motivates financial flows of various kinds, such as trade credit, bank loans, and speculative finance. Our goal in this paper is thus not to separate out trade flows from financial flows but rather to examine the extent to which the structure of the international trade network can explain the transmission of crises. We use trade flows to chart the structure of the network because these statistics are widely available and consistently measured across countries, as well as being highly correlated with other cross-country linkages.

Considering the pattern of international trade linkages explicitly as a network enables us to obtain indicators of country-level "integration" measuring how well-connected a country is into the global trading system. The core of our empirical analysis is based on three distinct network measures of country-connectedness into the global trading system. The first, known as Node Importance, is an index of network dependency in which nodes are defined as more important if others nodes depend more on them and if the other nodes depending on them are themselves important. For the international trade network, exporting countries depend on the importing ones for revenues. We therefore use export shares to construct a dependency matrix. A country that is more important according to this measure is likely to have a greater influence on the network if it is affected by an adverse shock such as a financial crisis. A second indicator is Node Centrality. Node centrality measures how central a given node is by measuring how "star-like" a node is relative to a perfect star, a node that is linked to every other. This can thus be considered an indicator of how well connected a country is into the international trade network. A third measure is Maximum Flow, which counts the number of paths, direct and indirect, that lead from a particular country (say country

\footnotetext{
${ }^{2}$ Complex networks are large scale graphs that are composed of so many nodes and links that they cannot be meaningfully visualized and analyzed using standard graph theory. Recent advances in network research now enable us to analyze such graphs in terms of their statistical properties. Albert and Barabasi (2002) and Newman (2003) are excellent surveys of these methods.
} 
i) to another country (say country $j$ ). In the context of financial contagion, this provides a measure of the number of paths via which a shock from a crisis "epicenter" country can potentially travel through the network to impact a "target" country $j$, directly and indirectly through intermediate countries. We describe these measures in more detail in section 2.

We examine how these network-based measures of country-level integration into the global trading system perform in explaining stock market returns during several recent crisis episodes. Since our goal is to isolate the impact of network interconnections, our empirical strategy focusses on five non-overlapping periods of financial crisis ${ }^{3}$ in order to prevent, to the extent possible, our results being "contaminated" by continuous turmoil in financial markets. We find that the adverse impact of a crisis on the stock market of a country is amplified if the epicenter country for a crisis is better connected according to these network measures. On the other hand, the impact of a crisis on any target country is dampened if the country in question is better connected into the trade network. The economic significance of network interconnections is considerable. As an illustration, the coefficient for the epicenter importance is -44.88 , implying that a one standard deviation increase in epicenter importance reduces our measure of stock market performance by almost 0.19 of a standard deviation. In the same regression, the coefficient for the importance of a target country $i$ is is 3.91 , implying that a one standard deviation increase in a target country $i$ 's importance translates into an increase of the stock market performance measure of 0.08 of a standard deviation. The economic magnitude of the effects of these changes on the weekly abnormal stock market return is a fall of 0.24 percentage points for the epicenter country network indicator, and an increase of 0.11 percentage points for the target country $i$ network indicator. Considering the fact that the average duration for the crisis windows exceeds ten weeks, the total cumulative effects are substantial. The results are qualitatively similar for the other network measures.

In other words, a better connected international trading network is a double-edged sword. A shock originating in a country (the epicenter) is likely to be amplified in terms of its impact on other countries if the epicenter country is better integrated into the trade network. But other countries affected by such a shock are in turn better able to dissipate the impact of

\footnotetext{
${ }^{3}$ These are crisis periods in the 1990's with the "epicenter" countries being Mexico, Venezuela, Thailand, Russia and Argentina. We describe our crisis definitions and crisis windows in detail in section 3.
} 
the shock if they are well integrated into the network. Based on this line of reasoning, a network approach can help explain why the Tequila Crisis, the Asian Flu, and the Russian Virus were highly contagious crises, while the financial crises that originated in Venezuela and Argentina did not have such a virulent effect. We elaborate on this in section 4.

The rest of the paper is structured as follows. Section 2 provides an overview of the recent debate on transmission channels for financial crises and explains the intuition behind

the network approach and the network measures we use in our empirical strategy. Section 3 describes our empirical methodology and data. Section 4 contains our principal empirical results. Section 5 provides robustness checks on our results. We conclude with section 6 .

\section{A Network Approach to Financial Contagion}

A poor understanding of the transmission of economic and financial crises has in the last few years prompted a surge of interest in international economic integration and its relationship to international financial contagion. The debate on the relative importance of trade linkages versus financial flows continues to be unresolved. A number of recent papers (Kaminsky and Reinhart, 2000, 2003; Bae, Karolyi and Stulz, 2003) have emphasized the importance of financial sector links in the propagation of crises across countries while others (Forbes, 2001; Forbes and Rigobon, 2001; Claessens and Forbes, 2001; Abeysinghe and Forbes, 2002) have stressed the importance of trade linkages.

Informal evidence suggests why this debate is unresolved. There is little direct trade between Brazil and Russia, and even minimal competition in third markets between these two countries. Brazil, however, was impacted by the Russian crisis in 1998, suggesting that trade linkages may not have been important in the transmission of this crisis. On the other hand, Argentina is one of Brazil's major trading partners. Argentina is also one of the countries most affected by Brazil's devaluation in 1999, suggesting that trade may have been important in the transmission of the Brazilian crisis. Other examples from the series of currency crises in the 1990's could support either of these arguments. However, both strands of research note that it is difficult to separate the two, because most countries that are linked in trade are also linked in finance.

The recent literature examining the role of trade in the transmission of crises has yet to 
reach a consensus. As a first pass at the issue, aggregate measures of bilateral trade do not seem to perform well in explaining crisis transmission (Kaminsky and Reinhart, 2000, 2003). However, the use of such aggregate measures masks the fact that trade can be parsed into several different and possibly counteracting channels, such as a competitiveness effect (when changes in relative prices affect a country's ability to compete abroad), an income effect (when a crisis affects incomes and the demand for imports), and a cheap-import effect (when a crisis reduces import prices for a trading partner and acts as a positive supply shock), which are found to be significant in explaining variation in stock market returns during recent crises (Forbes, 2001). In a similar vein, research using new and more detailed data that decomposes stock market returns into various factors (global, sectoral, and cross-country) finds that direct trade linkages appear to be the strongest and most important determinant of cross-country linkages in both stock and bond markets (Forbes and Chinn, 2003). The importance of trade linkages has been further emphasized in a recent investigation by Abeysinghe and Forbes (2002) who use a structural VAR model to find that even weak trade linkages can transmit shocks across countries quite powerfully through indirect multiplier effects on output and growth ${ }^{4}$.

Nevertheless, one consideration that is conspicuously absent from the current literature is the idea that since countries are interconnected through trade linkages, a shock originating in one country can be transmitted and amplified because of the pattern of interconnections in the network. Consider an example with three countries, A, B, and C as depicted in Figure 1 below. First assume that $\mathrm{A}$ has trade links with $\mathrm{B}$ and $\mathrm{C}$, but $\mathrm{B}$ and $\mathrm{C}$ do not trade with each other. To fix ideas, suppose that the linkages embody trade credit relationships derived from trade in intermediate inputs. In other words, suppose firms in A have bought intermediate inputs from firms in $\mathrm{B}$ and $\mathrm{C}$ and have paid only a fraction of the price as a down payment upon delivery. The remainder of the price will be paid upon realization of

\footnotetext{
${ }^{4}$ There are a number of earlier studies that find the trade channel to be a significant explanation for contagion. Eichengreen et al. (1996) analyzed contagion using data on 20 industrial economies from 1959 to 1993. They find that the probability of a crisis in a country increases the presence of a crisis elsewhere, and that this increase is better explained by trade links among countries than by macroeconomic similarities. Glick and Rose (1999) use a much larger sample of countries and find that trade competition in third markets has high power in explaining contagion in five major crisis episodes between 1971 and 1997.
} 

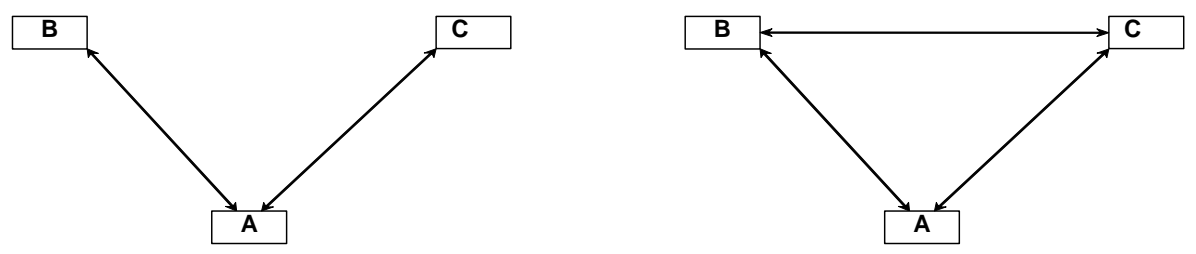

Figure 1: Interlinked Trade Credit Example

sales of the final product. It could also be that firms in A (either the same firms or different firms) have provided intermediate inputs to firms in B and $\mathrm{C}$ on similar terms. These kinds of trade credit relationships are conventional and ubiquitous in international trade. In this situation if a negative shock hits country A, firms in A may be forced to default on their input suppliers in B and C. Thus a shock originating in country A will have an impact on B and $\mathrm{C}$ and any effects on B and $\mathrm{C}$ will "boomerang" back to A only through separate bilateral links. This would be case if the linkages are as depicted in the left hand panel in Figure 1. If however, $\mathrm{B}$ and $\mathrm{C}$ are also trading partners then any direct effect of the shock from $\mathrm{A}$ to $\mathrm{B}$ will ripple through to $\mathrm{C}$ and vice-versa. These "second-order" effects will in turn affect A. This cascade of interdependent ripples may amplify the magnitude and duration of the initial shock to A. This would be the case if the linkages are as depicted in the right hand panel in Figure 1.

The structure of interlinkages could also play a role in dampening the impact of a shock originating in some other country. Suppose again that A is the "epicenter" of an initial shock. If B is not linked to countries other than A, then B has to absorb the full brunt of the shock that is transmitted from A through its link with A. However, if B trades with other 
countries, then it may be able to spread the impact of it's shock among its trading partners, thereby cushioning the blow. Again, in a trade credit context, if A defaults on an outstanding balance to $\mathrm{B}$ and $\mathrm{B}$ is an intermediate link in a credit network, $\mathrm{B}$ can in turn default on a proportional basis on its trade creditors. But if B is the final node in the chain then B has to absorb the full effect of A's default by itself. It is a short step from here to argue that the denser the network of linkages the greater the potential for such interdependent ripple effects, that could potentially amplify or dampen a shock. The incorporation of such considerations may go toward clarifying some of the puzzles regarding transmission through trade linkages and asymmetric effects on different countries that we described earlier.

Recent work by Kiyotaki and Moore $(2002,1997)$ lays out a full model of balance sheet contagion motivated by trade credit. They model the propagation and dampening of shocks along a trade credit network along the lines we describe here. We therefore do not go into the details of a full model as our intention in presenting this example is only to provide intuition for propagation and dampening of shocks through network interconnections.

\subsection{Network Measures}

A network is a set of points, called nodes or vertices, with connections between them, called links or edges. In our context, each country is considered to be a node of the network. Just as nodes and links are the basic components of any network, node degree is the basic component of complex network analysis. The degree is the number of links connected to a given node. Since international trade is usually measured using the monetary value of exports and imports between countries, trading relationships are analogous to valued links in a network, and these vary from country to country. In order to chart the structure of the network for the present purposes we wish to take into account the magnitude of these relationships but not specifically their exact value.

We do this by considering a network link between two countries to be present if the trade level between them is above a certain threshold. Specifically, we define a trade-link between country $i$ and country $j$ to be present if the value of exports from country $i$ to country $j$ as a proportion of country $i$ 's total exports is greater than or equal to a given magnitude. Since trade levels vary considerably from country to country and there could 
be debate over what constitutes "meaningful" levels of trade, we construct the network for different trade level thresholds, which we explain in the data and methodology section below. By examining how the structure of the network changes as the trade threshold used to define the presence of links varies, we are able to understand the sensitivity of the country-level network connectedness measures to differing trade magnitudes. Constructing the network for different thresholds thus enables us to incorporate both magnitudes and network features and adds to the robustness of our analysis. In the robustness section we also compute the network indicators using an alternative dependency measure, exports of country $i$ to country $j$ out of country $i^{\prime} s$ GDP, to define trade-links.

Network data can be presented in matrix form, where rows and columns headings represent nodes and the cells of the matrix describe the type of association between each node. It is standard in the networks literature to use rows for the source nodes and columns for receivers. The values of the cells are zeros when the nodes in question are not linked and ones when they are. For a network with a small number of nodes it is easy and appealing to use a graphical representation. However, as the number of vertices increases, graphical analysis of the network becomes more difficult and its characteristics and patterns are hard to identify through the naked eye and statistical analysis using the network represented as a matrix becomes indispensable.

Recent advances in complex network analysis ${ }^{5}$ provide us with a number of measures that we can use to understand how well connected an individual country is into the network and assess the level of influence that it has on other countries (nodes) and on the network as a whole (Hanneman 2001). These indicators, which incorporate information on volumes of trade, also take into account the number of trading partners, the position in the network of the country in question, and the degree of influence that a country has on others. Our empirical strategy uses the following network measures ${ }^{6}$.

\section{Node Degree Centrality}

The number of in and out-bound links will ultimately determine the connectivity of an individual node, but there are different ways in which this connectivity can be measured. The

\footnotetext{
${ }^{5}$ Watts (2003) and Newman (2003) are good overviews.

${ }^{6}$ The Node Degree Centrality and Maximum Flow Indiactors have been calculated using UCINET 6.7 software.
} 
simplest of these measures is Node Degree Centrality. The degree centrality of an individual node can be simply represented by its degree, but a more standard way is to normalize the individual node centrality in the following fashion,

$$
C_{D}(i)=\frac{d_{i}}{g-1}
$$

where $g$ denotes the number of nodes in the network and $d_{i}$ stands for the degree (number of links) of node $i$. This index shows which countries are at the core or close to the core of the network. If a country is at the core of the network then its node degree centrality will be close to one. For a periphery country, this number will be close to zero, given that the number of international trade linkages of such a country will be relatively small.

As ranked in Table 1, countries such as Brazil, South Korea, Indonesia, Malaysia, the Russian Federation, Thailand, and Turkey are among the top thirty five (some in the top fifteen) most central countries in the international trade network. The indices for the whole sample of countries (182) are available in a data appendix from the authors ${ }^{7}$. This is especially noteworthy since these countries have been at the epicenter of several financial crises and contagion episodes of the nineties. This is suggestive of the importance of international trade linkages for financial contagion.

[Table 1 about here]

\section{Node Influence or Importance}

Node degree centrality provides a preliminary approach to the identification of influential nodes. It is based on the number of countries that can be reached through direct links by an individual country. But it misses important features of the international trade network. The number of trading partners is a relevant statistic, but the specific characteristics of these trading partners may amplify or dampen the influence that a specific country has on others and on the whole network. One could say that it is not only the quantity of your partners that matter for influence, but also how influential they are in turn. If country A trades with country B and B trades with fifty other countries, then A exerts indirect influence on these fifty countries.

\footnotetext{
${ }^{7}$ We intend to post the data appendix with all the data on the internet in due course. It can also be obtained upon request from the authors.
} 
In a prominent paper, Salancik (1986) argues that "Accurate assessments of the structural power of several interdependent parties are hampered by the fact that parties depend on one another indirectly as well as directly and that any one's dependencies are not equally important for all parties." He goes on to propose an index for dependency networks in which nodes are defined as more important if others nodes depend more on them and if the other nodes depending on them are themselves important. Applying his index to our context, the importance of country $i$ is a function of the dependence of other nodes on $i$ and the importance of these other nodes.

$$
i m p_{i}=\sum_{j} d e p_{i j} i m p_{j}+i n t_{i} \text { for all } j \neq i
$$

where $i m p_{i}$ is the importance of country $i, d e p_{i j}$ is the extent to which country $i$ is depended upon by country $j$, and $i n t_{i}$ denotes the intrinsic value of country $i$. Equation (2), which represents a system of $i$ equations, determines that if a country is not depended upon by other countries, then it will be unimportant. Also, if a country is depended upon only by unimportant countries, then it would also be considered unimportant.

Equation (2) can be rewritten in matrix form as,

$$
I M P_{i}=[D]_{i j} I M P_{i}+I N T_{i}
$$

where $[D]_{i j}$ denotes the matrix of dependencies of each country $j$ on each country $i$. For the international trade network, exporting countries depend on importing ones. Therefore we use as the elements of $[D]_{i j}$ the share of exports of country $j$ to country $i$ out of the total exports of country $j$. We use the world trade share of a country as a measure of its intrinsic importance. Note that since the matrix of dependencies uses the raw trade share data instead of a binary matrix based on trade-link thresholds, the node importance measure is free of threshold considerations. In the robustness section we consider other measures of dependency and intrinsic value.

Table 2 shows the rankings for the top thirty five countries, but the indices for all one hundred and eighty two countries are available in a data appendix from the authors ${ }^{8}$. Once again it is worth noticing that the countries that were at the epicenter of the economic crises of

\footnotetext{
${ }^{8}$ We intend to post the data appendix with all the data on the internet in due course.
} 
the nineties appear near the top of the list of country level importance for the international trade network. It is also noteworthy that country rankings according to importance are starkly different from those obtained when countries are ranked according to the ratio of total trade (exports plus imports) to GDP, the standard trade openness measure used in the literature.

\section{[Table 2 about here]}

\section{Maximum Flow}

Another way to measure the influence that a given country has on others is by counting the number of direct and indirect ways in which a shock to the country in turn affects others. When a particular country is hit by a shock that forces a reduction of its domestic demand for foreign goods, this translates into a diverse number of direct and indirect hits on a number of countries in the international network. A reduced demand for foreign goods in country A translates into a reduced cash flow for country B, given that this country's exports to A have decreased. In turn, country B's domestic demand for foreign exports from country C may drop and this implies an indirect effect of a shock to A on country C. Given the size and structure of the international trade network, shocks to one country translate into a cascade of direct and indirect effects on other countries. A meaningful indicator would be one that captures the number of times, directly and indirectly, that a shock from country A translates into effects on all the other members of the network. Such a measure has been used in complex network analysis and has been termed maximum flow (Hanneman, 2001).

In simple terms, the maximum flow measures the number of nodes in the neighborhood of a source that lead to pathways to a target. If a shock to country A can only be transmitted to country $\mathrm{C}$ through country B then the connection of country A is weak (even if B affects $\mathrm{C}$ through many other countries). On the other hand, if a shock to $\mathrm{A}$ is transmitted to $\mathrm{C}$ via three different countries (each of which has one or more ways in which the shock is transmitted to C), then A's connection is stronger.

Table 3 shows the top thirty countries ranked according to this methodology. Once again the countries that were behind the crises and contagion effects observed during the nineties appear near the top of this list. In fact in some cases, these countries are ranked higher than 
or are tied in rank with G-7 countries. It is also instructive to use maximum flow to look at specific cases, such as the countries involved in the contagion that started in 1997-1998 with the crisis of Thailand and ended with the collapse of Argentina in 2002. Thailand devalued its currency in July of 1997. This event ignited the east Asian crisis in which Indonesia, Malaysia and Korea were the main participants. The contagion effect of these events reached Russia and Brazil in 1998, when the Ruble and the Real were devalued and flexible exchange rate regimes were adopted in both countries. Thereafter Ecuador, Turkey and Argentina collapsed in 1999, 1999 and 2001, respectively.

[Table 3 about here]

From the maximum flow matrix it is possible to identify the countries that would be more severely affected, directly or indirectly, by a shock to a given country. Table 4 lists the top thirty five countries, and the number of paths leading to them, that would be affected by shocks to Mexico (1994), Venezuela (1995), Thailand (1997), Russia (1998), Argentina (2000) and Brazil $(1998)^{9}$, according to the maximum flow measure at the one percent trade-link threshold. These results show that it is possible to identify Brazil, Indonesia, Korea and Russia as candidate countries for severe aftershocks of the Thai currency devaluation. A similar picture emerges when we look at the corresponding list for Russia. The list for Brazil shows that the impact on Argentina, which was directly affected by the devaluation of the Real in 1998, was to be expected due to their close ties through MERCOSUR. The maximum flow index is thus potentially of value for the study of financial contagion.

\section{[Table 4 about here]}

However, while the maximum flow is an instructive measure, it suffers from the drawback that the different paths leading from the epicenter country to country $i$ are not distanceweighted. In other words, a direct path is considered as important as one that went through $n$ other countries. Hence it is important to keep this caveat in mind when considering this measure.

\footnotetext{
${ }^{9}$ The data for Argentina in 2000 is used in our analysis as a proxy for the 2001 data, since the data for international trade was only available through 2000.
} 


\section{Methodology and Data}

Our empirical methodology examines how the network-based measures of country-level integration into the global trading system described above perform in explaining stock market returns during several recent crisis episodes. The data we use for the computation of the network and associated measures was extracted from the NBER-UN world trade database ${ }^{10}$. Countries are considered nodes of the network and a link between them represents a trading relationship. We use the U.S. dollar value of exports and imports of all commodities between 182 countries for the years 1992 through 2000. Our trading relationships are based on the flow of payments between countries. Exporting countries are thus recipients of payments for their exports, while importing countries are sources of payments for their imports. This approach allows us to capture the influence of importing countries on exporting ones as influential buyers. We use the share of exports of country $i$ to country $j$ out of the total exports of country $i$ to define the presence of a trade-link between $i$ and $j$, and construct binary matrix representations of the international trade network for different magnitudes of this trade ratio. Thus, if country $i$ 's exports to country $j$, out of the total exports of country $i$ are greater or equal to a given threshold, then the link $j \rightarrow i$ is defined as present. We construct the network and associated network measures for several different values of the trade-link threshold. The specific thresholds we use are zero, one, and two percent. The zero percent threshold indicates the mere existence of trade among two countries and in this sense it is the least restrictive threshold. It simply acknowledges the presence of positive trade. We choose the one and two percent thresholds because eighty eight percent of the trade shares in 1992 (eighty nine percent in 2000) are between zero and one percent, and this number increases to ninety two percent when the range between zero and two percent is considered for the 1992 data (and the same is observed in 2000). Therefore we could say that these thresholds are close to embodying meaningful or representative trade. As mentioned earlier, using thresholds enables us to avoid working directly with valued links even though implicitly these thresholds embody the values of the trade links in our data.

In order to examine how these measures perform in explaining stock market performance

\footnotetext{
${ }^{10}$ This database is available online at www.nber.org/data (International Trade Data, NBER-UN world trade data). A detailed description of the database can be found in Feenstra et al. (2005).
} 
during recent periods of crisis (referred to as crisis windows), we follow the approaches of Rigobon (2003), Forbes (2001) and Glick and Rose (1998) to specify the time-periods for our study. Rigobon (2003) and Glick and Rose (1998) base their studies on non-overlapping crises windows in order to prevent, to the extent possible, the analysis from being "contaminated" by continuous turmoil in financial markets. Rigobon (2003) specifies three such windows: the Mexican crisis in 1994 - 1995, the Asian crisis 1997 - 1998, and the Russian crisis in 1998 - 1999. The selection criteria used to determine these windows is based on the empirical fact of observed low-volatility (tranquil) periods prior to these crises, followed by high-volatility periods after a specific date. Glick and Rose (1998) consider five different crises, pinpointed by the occurrence of currency crises - the breakdown of the Bretton Woods system in 1971, collapse of the Smithsonian Agreement in 1973, the EMS crisis in 1992 - 1993, the Mexican meltdown in 1994 -1995, and the Asian flu of 1997 - 1998. Forbes (2003) follows a more conventional approach and builds an "exchange-market pressure index" which is a function of the observed variations of the exchange rate, interest rate, and international reserves of a given country ${ }^{11}$. Based on this index, for the period of July 1, 1994 - June 31, 1999, she determines the occurrences of crises. Specifically, if the index of country $i$ at time $t$ exceeds a given threshold, then a crisis is considered to have occurred in period $t$. Three different thresholds are considered to identify crisis periods of varying intensity: $\mu \pm 5 \sigma, \mu \pm 3 \sigma$, $\mu \pm 1.5 \sigma$, where $\mu$ and $\sigma$ denote the mean and the standard deviation of the exchange-market pressure index. Applying this methodology to the data results in the identification of sixteen (sometimes overlapping) crises windows, which are listed in Table 5. Thus, following the lead of Rigobon (2003) and Glick and Rose (1998) regarding non-overlapping crises, and the results obtained by Forbes (2001) through the analysis of the EMP, we select five nonoverlapping crises windows for our analysis. The crisis windows we use for our analysis are also listed in Table 5.

\section{[Table 5 about here]}

Since our interests lie in investigating network effects using international trade linkages

\footnotetext{
${ }^{11}$ The argument in favor of such an index, widely used in the literature, is that it captures the main tools that central banks can use to fight-off an speculative attacks and/or adverse market behavior in response to new information. For further discussion see Eichengreen, Rose and Wyplosz (1996).
} 
as the backbone for the analysis, we specify not only crisis windows but also an epicenter country for each crisis. The selection of the epicenter is not random. Rigobon (2003) traces the beginning of each high volatility window to a specific country. This can be seen in Table 5, which shows the crisis windows identified by Rigobon (2003). Venezuela is chosen as the epicenter country of our second crisis window since in Forbes' (2001) study it is the first $\mu \pm 5 \sigma$ country after a relative tranquil period that followed the Mexican Crisis in 1994. We also include the Argentine crisis of 2001, a crisis not considered in the studies described above. In June 2001 the Argentine government performed a debt swap of over thirty billion US dollars worth of bonds. Even though the swap was initially considered a success, within weeks the Argentine markets, and others within the region, were in distress and this forced Argentina to turn again to the IMF. This marked the beginning of the end for the currency board in Argentina, a system that was removed entirely in January 2002 when the government announced a formal default on its debt.

The base econometric model we use for the subsequent analysis is the following:

$$
S M R_{i, w}=\beta_{1} N I C_{i, w}+\beta_{2} N I E C_{w}+\sum_{k=1}^{K} \gamma_{k} Z_{k, i, w}+\varepsilon_{i, w}
$$

where $S M R_{i, w}$ denotes the stock market performance indicator for country $i$ during crisis window $w, N I C_{i . w}$ and $N I E C_{w}$ represent the network indicator for country $i$ and the network indicator for the epicenter country during crisis window $w$, respectively. The $Z_{k, i, w}$ 's denote control variables, most of which are the standard macroeconomic determinants of currency, banking, and financial crises. Following Forbes (2003) these variables are measured during the year prior to the starting date of the crisis window considered. In addition, we also include a control variable for trade between the crisis epicenter country and country $i$ in order to account for a direct bilateral transmission channel between the two countries. A direct bilateral link is arguably a potent transmission channel, and we include it in order not to confound network effects with the direct effect that is due to trade with the epicenter. In such a framework, network effects, if obtained, should be considered especially relevant.

We are interested in explaining how country $i$ 's vulnerability (assessed by stock market performance during a particular crisis window) is affected, positively or negatively, by the network characteristics of country $i$, as well as those specific to the crisis epicenter country. 
Based on the intuition from the previous section, our priors are that the better connected the epicenter country is to the whole network, the greater will be the impact on the network and on country $i$ of a shock to the epicenter country. Also, following the intuition presented earlier, we expect that a better connected country $i$ will be less affected by shocks to other countries, since it can dissipate the negative impact among its many (links) trade partners.

The stock market performance indicator is computed by calculating the deviations of the weekly average stock market return of country $i$ during crisis window $w$ from the weekly average of the stock market return of country $i$ for the period between January 1992 (the first observation of our dataset) to December 1994 (last observation before the Mexican crisis). This indicator can therefore be considered a measure of abnormal returns. Weekly stock market data from January 1992 to December 2002, extracted from Bloomberg, was used to compute the weekly average abnormal stock market returns for each crisis window. The resulting dataset includes data on forty one countries. The reason for limiting the time period for the baseline stock market average (the mean from which the deviations are measured) to January 1992 through December 1994 is because this period is characterized by relatively stable macroeconomic and financial conditions through out the world. Forbes (2003) uses a similar abnormal returns indicator, but she computes the deviations of stock market returns from the mean of the stock market in the previous year. We believe that although this measure is a good measure of abnormal returns for the Mexican crisis, since the period preceding this event was relatively tranquil, it is not for the other crisis windows, since from 1995 onwards the world was characterized by a wide array of crises, including balance of payments, exchange rates, and financial and banking crises. In section 5, as a robustness check, we replicate the analysis using a different definition of the abnormal returns. Specifically, we use the overall average return for a longer time period, from January 1992 to December 2002, as the mean from which the weekly abnormal stock market deviations are calculated. The results using this alternative definition of abnormal returns are similar to the primary results presented in the next section.

The macroeconomic control variables considered for the estimation of the base model, equation (4) are bank reserves to assets ratio, yearly inflation rate (CPI), GDP growth rate, current account balance, government expenditures, overall government budget balance, pri- 
vate capital flows, and total trade as percentage of GDP. These variables, or the data necessary for their computation, was extracted from the World Development Indicators Database (WDI). The bilateral link variable is trade with epicenter, measured as the ratio of trade between country $i$ and the epicenter to the total trade of country $i$. The data appendix presents a detailed explanation of these variables and lists the specific WDI codes. Merging the stock market data with the data for the macroeconomic control variables and network indicators for the five crisis windows leads to a panel of 34 countries when all the control variables are included. The list of countries, and tables presenting descriptive statistics are in the appendix at the end of the paper.

For robustness, section 5 presents results obtained using a different dependency measure for the computation of the network indicators. Instead of the original dependency measure described above, i.e., share of exports of country $i$ to country $j$ out of the total exports of country $i$, we use instead the value of the exports of country $i$ to country $j$ out of country $i^{\prime} s \mathrm{GDP}^{12}$. The original dependency measure can be considered a measure of cash flow dependency, since exports ultimately represent cash flows to the exporting country. The modified dependency statistic can be thought of as an economy wide dependency measure, i.e. how country $i$ 's economic activity depends on the sales to country $j$. The GDP data used for these calculations was extracted from the World Development Indicators database of the World Bank ${ }^{13}$. We should note that the time period covered for the analysis is 1992 to 2002, but the trade data is only available up to 2000. We therefore use the network indicators computed using the 2000 data for the analysis of the Argentine crisis window (June 2001 April 2002).

\section{Results}

We present the results for the estimation of the base model using the original definition for the weekly abnormal stock market returns, the trade based network indicators (i.e. trade-link

\footnotetext{
${ }^{12}$ The one and two percent thresholds are still appropriate when using this dependency measure since in ninety seven percent of the cases export to GDP ratios are between zero and one percent in 1992 (ninety six percent in 2000).

${ }^{13}$ Specific details are listed in the data appendix at the end of the paper.
} 
threshold defined by using exports of country $i$ to country $j$ out of total exports of country $i$ ) and all the control variables. In section 5 , the robustness section, we present and discuss the results obtained for the cases where the GDP based indicators and the alternative definition for the abnormal stock market returns are considered. A close examination of equation (4) shows that with the inclusion of the network indicator of the epicenter, NIEC $C_{w}$, the regression resembles a fixed time-period effects model; therefore there is no need to control for this type of effect in our estimation. On the other hand, there could very well be fixed cross-section effects $^{14}$. We explore this possibility, but the results for the $F$ and Chi-square tests (for the redundant fixed effects - Likelihood Ratio test) cannot reject the null hypothesis of redundant fixed effects, for any of the cases considered. We estimate the base model using OLS and also through generalized least squares, GLS, exploring the possibility of cross-section specific heteroskedasticity.

Table 6 presents the results of the estimations of the base model using two different network indicators, node importance and node centrality, and all the control variables. The results for node importance are presented for two cases, one where the world trade share of country $i$ (total trade of country $i$ out of total world trade) is used for intrinsic value ${ }^{15}$, and the other where the node centrality at the one percent trade-link threshold for country $i$ is used as the intrinsic value. For the case of node centrality, the table presents results for three different trade-link thresholds defining the network: zero, one, and two percent. Odd numbered columns present the results estimated through OLS, while even numbered columns show the results obtained via GLS.

\section{[Table 6 about here]}

A first glance at Table 6 shows the strong statistical significance of the network indicators. The coefficients for the epicenter indicators are statistically significant across the board,

\footnotetext{
${ }^{14}$ In the robustness section we present and discuss the results obtained by estimating an alternative model. Instead of using the network indicators for the epicenter country, we use a dummy variable for each of the crisis windows (in essence a time period fixed effects model). There we show that the results of the fixed effects model match those presented here.

${ }^{15}$ Total world trade shares were calculated with the same data used for the computation of the network indicators.
} 
except in regression (9), and are all negative, while those for the network indicators of country $i$ are of the right sign $(+)$ and statistically significant in six out of the ten regressions presented. More importantly, the economic significance of these variables is considerable. For example, the coefficient for the epicenter importance in regression (2) is -44.88 (significant at the one percent level), implying that a one standard deviation increase in epicenter importance will reduce the abnormal return (meaning it affects stock market return negatively) by almost 0.19 of a standard deviation ${ }^{16}$. Regarding the importance indicator of country $i$, the coefficient of this variable in regression (2) is 3.91, implying that a one standard deviation increase in country $i$ 's importance translates into an increase of the abnormal stock market return (i.e., it positively affects stock market performance) of 0.08 of a standard deviation. The economic magnitude of the effects of these changes on the weekly abnormal stock market return is a fall of 0.24 percentage points for the epicenter country indicator, and an increase of 0.11 percentage points, for the country $i$ indicator. For the centrality indicators, using the results for the one percent threshold (i.e. regression (8)) for example, the effect of a one standard deviation increase in epicenter centrality leads to a decrease of the weekly abnormal stock return of 0.07 of a standard deviation, or 0.09 percentage points. The increase of a one standard deviation of country $i$ centrality results in an increase of the the weekly abnormal return by 0.043 of a standard deviation, or 0.055 percentage points. Considering the fact that the average duration for the crisis windows exceeds ten weeks, the total cumulative effects are substantial. Instead of discussing the specific magnitudes for each of the coefficients for the network indicators for each regression, we show the estimated effects for all of them in Table 7. The results are consistent across the board, in the sense that effects of the network indicators are considerable ${ }^{17}$.

\footnotetext{
${ }^{16}$ The Data Descriptive Statistics table, presented in the Appendix at the end of the paper, reports that the standard deviation of the abnormal stock return is equal to 1.27 , while that for the importance of the epicenter country, using the world trade share as the intrinsic value, is 0.00533 . Therefore a one standard deviation of epicenter importance implies a change of -0.24 percentage points in the abnormal stock return $(-44.88 * 0.00533)$, which is about 0.187 of a standard deviation of the dependent variable $(0.24 / 1.27)$.

${ }^{17}$ It is also worth noting that results for two distinct node importance indicators are presented in Table 6 . The results obtained using the centrality of country $i$, at the one percent threshold as the intrinsic value of the node (columns 3 and 4) are similar to those obtained when world trade share of country $i$ is used as the intrinsic value (columns 1 and 2). Recall from our description of node importance in Section 2 that it is free
} 
[Table 7 about here]

The Tequila Crisis, the Asian Flu, and the Russian Virus were highly contagious crises, while the financial crises that occurred in Venezuela and Argentina did not have such a virulent effect. The results presented in Table 8 suggest that network effects may be able to explain some of these differences between crises. Table 8, using the estimated coefficients of regression (2) in Table 6, and the network importance indicator, shows that the epicenter network effect on other countries was substantially higher for the Tequila, Asian Flu, and Russian Virus crises than for the Venezuelan and Argentinian crises $^{18}$. Table 8 also shows how better connected countries, like the US, Canada and Italy can dampen the negative effects of shocks originating in other countries, while less connected countries like Ecuador, India, Venezuela and others cannot. For example, during the Asian Flu the magnitude of the effect from the epicenter country, based on the results for the importance indicators that use world trade shares as intrinsic values, was a decrease of the abnormal weekly stock market return of 0.51 percentage points for all countries. But the US, since its importance indicator is high, dampens the effect by 0.58 percentage points. In contrast, countries like Greece and Venezuela, on account of a low value of importance in the network, can only dampen this negative effect by 0.01 percentage points ${ }^{19}$.

\section{[Table 8 about here]}

The third network indicator presented in section 2.1 was Maximum Flow. This particular indicator measures the influence that a given country has on the network by counting the number of direct and indirect ways in which a shock to the country in turn affects others. More specifically, it is possible to measure the number of paths through which a shock originating in country $i$ can be transmitted to country $j$ ( i.e. the maximum flow from country $i$ to country $j$ ). We use this measure to estimate the following specification of the base model,

of threshold considerations since it is based on raw trade share data. This gives additional confidence in the measures based on trade-link thresholds.

${ }^{18}$ Similar results hold if the other regressions are used for this analysis

${ }^{19}$ These calculations used the data of the network indicators for each country and the estimated coefficients of regression (2) in Table 6 . 


$$
S M R_{i, w}=\beta_{1} \operatorname{Maxflow}(e \text { to } i)_{i, w}+\sum_{k=1}^{K} \gamma_{k} Z_{k, i, w}+\varepsilon_{i, w}
$$

where Maxflow (e to $i$ ) denotes the maximum flow measure from the epicenter country to target country $i$. Once again, we estimate this model using OLS and also through generalized least squares (GLS), exploring the possibility of cross-section specific heteroskedasticity. We do not wish to emphasize the results obtained through this network measure because maximum flow has the shortcoming that different paths leading from the epicenter country to country $i$ are not distance-weighted. In other words, a direct path is considered as important as one that went through $n$ other countries. It is important to keep in mind this important caveat with this measure. Nevertheless, we include the results as they may be instructive. We present the results for the zero, 0.5, one, and two percent thresholds. We include the 0.5 percent threshold for this analysis because we believe that the zero percent threshold results are over-inflated, while the 0.5 threshold reduces this bias to some extent but is not so restrictive as the one and two percent thresholds. The results presented in Tables 9, odd numbered columns for OLS results and even numbered for GLS, show that the network indicator is statistically significant for the GLS regressions that use the maximum flow indicator at the 0.5 and the one percent thresholds. The estimated coefficient for maximum flow in regression (4) of Table 9 implies that a one standard deviation increase of the maximum flow from the epicenter to country $i$ brings about a decrease in the abnormal weekly stock market return of 0.06 of a standard deviation or about 0.075 percentage points. Comparing these results to those obtained for the other two network indicators, node importance and centrality, we can conclude that the signs coincide but the magnitude of the effects is lower.

[Table 9 about here]

\section{Robustness and Sensitivity Analysis}

To check the robustness of the previous results, in this section we present results for different specifications of the base model, equation (4), using alternative definitions for the dependent variable abnormal stock market returns, and the network indicators. Previously we defined abnormal stock market returns as deviations of the average stock market return of country 
$i$ during crisis window $w$ and from the average of the stock market return of country $i$ for the period of January 1992 (first observation of our dataset) to December 1994 (last observation before the Mexican crisis). The definition considered here computes these deviations from the average of the stock market return of country $i$ for the whole sample period (January 1992 - December 2002). With regard to the network indicators, in the previous section these were computed using the ratio between the exports of country $i$ to country $j$ out of the total exports of country $i$ to define trade-links. In this section the network indicators used are obtained using an alternative dependency measure, exports of country $i$ to country $j$ out of country $i^{\prime} s$ GDP, to define trade-links. We also perform sensitivity checks for our results by considering subsets of our sample period for some of the alternative specifications considered for the robustness analysis.

The regression results presented in Table 6 use all the macroeconomic control variables to estimate the base model, equation (4). Table 10 shows the results for the estimation of the base model using different subsets of the macroeconomic control variables. Regressions (1) through (5) use macroeconomic control variables that are usually associated with the analysis of financial and currency crises: bank reserves to assets ratio, current account deficit, private capital flows and government expenditures, while regressions (6) through (10) use the rest of the control variables. Henceforth we refer to the these two groups of regressions as specifications A (1 through 5) and B (6 through 10), respectively. We only report the results for the GLS methodology since the estimated coefficients for the network indicators are lower than those obtained through OLS and this therefore keeps our reported results on the conservative side ${ }^{20}$. It is clear that the results for the network indicators, using the original definition for the dependent variable, are robust across specifications (A and B). The statistical significance of the network indicators is very strong and their economic significance is similar to that reported for the original specification of the base model. For example, using the results from regression (1), the estimated coefficient for node importance, -22.9 , implies that a one standard deviation increase in epicenter node importance leads to a decrease of the abnormal stock return by 0.10 of a standard deviation, or about 0.12 percentage points.

\footnotetext{
${ }^{20}$ This can be verified in Table 6 . It should also be noted that the statistical significance of the network indicators and the macroeconomic control variables of the OLS regressions for the specifications A and B very closely follows the results presented in Table 6 .
} 
Regarding the effects of country $i$ 's importance, the estimated coefficient is 4.32 , meaning that a one standard deviation increase in country $i$ 's importance translates into an increase of the abnormal stock market return of 0.09 of a standard deviation or 0.12 percentage points.

[Table 10 about here]

Similar conclusions apply for the results shown in Table 11, where the regressions use the alternative definition of the dependent variable for the three different specifications considered previously, i.e. all control variables (panel 1) and the two subsets (A and B) described above $\left(\right.$ panel 2) ${ }^{21}$. For Panel 1 in Table 11, odd numbered regressions present the results for OLS while even numbered ones do so for GLS. Regarding Panel 2, we only present the GLS results for the same reasons discussed above for Table 10. As a final check we reestimate the regressions used to obtain the results in Tables 6,10 , and 11 using the alternative computation of the network indicators. That is, we compute the network indicators using exports of country $i$ to country $j$ out of country $i^{\prime} s$ GDP to define trade-links instead of the original dependency measure, exports of country $i$ to country $j$ out of the total exports of country $i$. The results for this robustness check exercise, presented in Tables 12 and 13 (odd numbered regressions - OLS while even numbered correspond to GLS in Panel 1 and GLS only in Panel 2), show no meaningful differences from those discussed above. The estimated coefficients for the network indicators for the epicenter country and for country $i$ are similar to those discussed previously. All of the coefficients have the right sign, negative for the epicenter effects and positive for that of country $i$, and are mostly statistically significant.

We do not discuss in detail the economic significance for each of the estimated coefficients for the epicenter and country $i$ 's network indicators in Tables 10 through 13, but Table 14 presents an overview of the results for the node importance network indicator that uses world trade shares as the intrinsic values. For reasons of space we do not present the results for all the network indicators, but it should be noted that just as the results presented in Table 14 show no meaningful differences from those reported in Table 7 for the node importance indicator (which uses world trade shares as the intrinsic value), the results for the other network indicators show no substantial differences either.

\footnotetext{
${ }^{21}$ The magnitude effects for the network coefficients is not presented or discussed here, but it is easy to verify that the results for these robustness checks match those presented in Table 6 .
} 
As mentioned earlier, the trade data needed to compute the network indicators for 2001 was not available to us. Therefore we used the network indicators for 2000 as proxies for 2001 values. Hence, as a final sensitivity check we exclude the fifth crisis window (Argentina) from the analysis. Table 15, which follows the same specification as Table 6, presents the results for this sensitivity check. The statistical significance and the magnitude of the effects are very similar to those obtained before.

\section{[Tables 11-15 about here]}

\subsection{Fixed Effects vs. Network Effects}

As a final comment we would like to mention that even though the estimated base model resembles a fixed time period effects model, there is a definite advantage to using the network approach. Table 16 shows the results obtained after re-estimating the base model, but instead of including the network indicators for the epicenter country, a fixed time period effects specification is used. These regressions use the original definition for the weekly abnormal stock market returns as well as the original dependency measure for the network indicators, exports of country $i$ to country $j$ out of the total exports of country $i$. These results show that the network effects for country $i$ are statistically significant when the network indicators considered are node importance with world trade share as intrinsic value, as well as node centrality at the two percent trade-link thresholds. But most importantly, Table 16 also shows the (recovered) fixed time period effect dummies for each crisis window. The magnitude of these effects are in line with those obtained when the network indicators for the epicenter country were used instead of using a fixed time period specification. The magnitude effects for the Mexican, and Asian crises (period effects 1 and 3) are substantially higher than those estimated for the Venezuelan, Russian and Argentinean crises (period effects 2, 4, and $5)$.

\section{[Table 16 about here]}

This similarity with the network approach notwithstanding, we see that the fixed effects specification does not fully capture the differences observed between the Argentine and Russian crises. Moreover, if the focus of the study is to analyze the possible implications of 
future crises, then the fixed time period specification is no longer useful while the network specification is still useful. The methodology using the network indicators can be used not only to describe and analyze previous crisis windows, but it can also be used as a predictive tool, albeit with caution given that these are estimated effects. It is possible to forecast the magnitude of the effect that a hypothetical crisis in India, for example, would have on the average weekly abnormal stock market returns. For this purpose the network indicators and the estimated coefficients presented in Table 6 can be used to forecast the epicenter country and country $i$ 's effects. For example, using the network indicators of 2000 for India as proxies for the current ones, it is possible to show that the network effects of the epicenter country (India) would be a decrease of the abnormal weekly stock market return 0.36 percentage points for all countries, a value that is a bit lower than that observed for Thailand and Russia during the Asian and Russian crises, respectively, but considerably higher than those observed for Argentina and Venezuela during their crisis windows ${ }^{22}$.

\section{Conclusion}

Given that countries around the world are tied together through a complex network of trade and financial linkages leading to a web of dependencies of various kinds between them, it seems reasonable to argue for a system-wide perspective on the transmission and diffusion of crosscountry shocks. The absence of research that incorporates system-wide considerations may be one reason why the literature on financial contagion continues to puzzle over why many of the recent crises that began in relatively small economies had such global repercussions and why shocks originating in one economy spread to some markets, while markets in other countries were relatively unaffected.

Using international trade data we build a network of the global trading system and use this network as the backbone upon which trade and financial flows between countries take place. We construct network based measures of country-connectedness into the system. When we use these network measures to explain the performance of stock markets in the wake of several recent crises, we find that being integrated into the international trading network is a double-edged sword. A shock originating in a country is likely to be amplified in terms of its

\footnotetext{
${ }^{22}$ This can be verified in Table 8 .
} 
impact on other countries if the epicenter country is better integrated into the trade network. But other countries affected by such a shock are in turn better able to dissipate the impact of the shock if they are well integrated into the network. These results are robust to the inclusion of a wide array of variables that control for standard macroeconomic determinants of currency, banking, and financial crises, a direct bilateral trade-based transmission channel between crisis epicenter country and target country, and a variety of sensitivity checks.

A network approach can advance our understanding of why the Tequila Crisis, the Asian Flu, and the Russian Virus were highly contagious crises, while the financial crises that occurred in Venezuela and Argentina did not have such a virulent effect. We find that the network effect of the crisis epicenter country was substantially higher for the Tequila, Asian Flu, and Russian Virus crises than for the Venezuelan and Argentine crises. We find that better connected target countries, like the US, Canada and Italy can dampen the negative effects of shocks originating in other countries, while less connected countries like Ecuador, India, Venezuela and others cannot. A network approach that is capable of incorporating the cascading of interdependent ripples that happen when a shock hits a specific part of the network may therefore provide us with a deeper understanding of economic and financial contagion.

Such an approach may also have useful policy implications. The actual structure of the interdependent global trade network can be used to model what would happen to the system if different parts of the network collapsed owing to economic crises or speculative financial attacks. In other words, "what-if" scenarios can be simulated with regards to crises originating in hitherto unexplored parts of the network. This analysis may provide predictive insight into the likelihood of contagion for hypothetical crises.

Moreover, since the actual structure of the international trade network evolves over time, and can in principle be monitored, it is conceivable that an understanding of the vulnerability of the network together with the topology of the network could be a potentially useful policy tool in discussions of optimal financial architecture and intervention by organizations such as the IMF and the US Treasury in the event of actual or anticipated crises. 


\section{References}

[1] Abeysinghe, T. and Forbes, K. (2002), "Trade Linkages and Output-Multiplier Effects: A Structural VAR Approach with a Focus on Asia." Forthcoming in the Review of International Economics.

[2] Albert, A. and A. L. Barabasi, (2002), "Statistical Mechanics of Complex Networks", Reviews of Modern Physics 74, 47.

[3] Bae, K-H., Karolyi, G. A. and R. Stulz, (2003), "A New Approach to Measuring Financial Contagion," Review of Financial Studies, 16(3).

[4] Claessens, S. and Forbes, K. (2001), "International Financial Contagion: An Overview of Issues," Introductory chapter of International Financial Contagion, edited by Stijn Claessens and Kristin Forbes. Kluwer Academic Publishers, pgs. 3-17.

[5] Eichengreen, B., A. Rose and C. Wyploz, (1996), "Contagious currency crises: first tests," NBER Working Paper 5681.

[6] Feenstra, R. C., R.E. Lipsey, Deng, H., Ma, A.C. and Hengyong Mo, (2005), "World Trade Flows, 1962-2000," NBER Working Paper 11040.

[7] Forbes, K. (2001), "Are Trade Linkages Important Determinants of Country Vulnerability to Crises," In Sebastian Edwards and Jeffrey Frankel, eds., Preventing Currency Crises in Emerging Markets. University of Chicago Press, Chicago, pgs. $77-124$.

[8] Forbes, K. and M. Chinn, (2004), "A Decomposition of Global Linkages in Financial Markets Over Time," Review of Economics and Statistics, 86(3): 705-722.

[9] Forbes, K. and R. Rigobon, (2002), "No Contagion, Only Interdependence: Measuring Stock Market Comovements," Journal of Finance, vol. LVII (5, October), pgs. 2223-2261.

[10] Glick, R. and A.K. Rose, (1998), "Contagion and Trade: Why are Currency Crises Regional?," NBER Working Paper 6806. 
[11] Hanneman, R.A. (2001) "Introduction to Social Network Methods," Mimeo. University of California, Riverside.

[12] Kaminsky, G. and C. Reinhart (2003), "The Center and the Periphery: The Globalization of Financial Shocks," NBER Working Paper 9479.

[13] Kaminsky, G. and C. Reinhart (2000), "On Crisis, Contagion and Confusion," Journal of International Economics, Vol. 51 No. 1, June 2000, 145-168.

[14] Kiyotaki, N. and J. Moore (1997), "Credit Chains," Mimeo, London School of Economics.

[15] Kiyotaki, N. and J. Moore (2002), "Balance Sheet Contagion," American Economic Review, v92, n2: 46-50.

[16] Newman, M. E. J. (2003), "The Structure and Function of Complex Networks", SIAM Review 45, 167-256.

[17] Rigobon, R. (2003), "On the Measurement of the International Propagation of Shocks: Is it Stable?" Journal of International Economics, Volume 61, 261-283.

[18] Salancik, G. (1986), "An Index of Subgroup Influence in Dependency Networks," Administrative Science Quarterly, vol. 31, 194-211.

[19] Watts, D. (2003), Six Degrees: The Science of a Connected Age, W.W. Norton, New York \& London. 
Table 1. Rankings for the Top Thirty Five Countries According to Node Centrality Index

\begin{tabular}{|c|c|c|c|c|c|c|}
\hline & \multicolumn{3}{|c|}{ Node Centrality (one percent threshold) } & \multicolumn{3}{|c|}{ Total Trade (Exports plus Imports) to GDP } \\
\hline & 1994 & 1997 & 2000 & 1994 & 1997 & 2000 \\
\hline USA & 1 & 1 & 1 & 156 & 154 & 148 \\
\hline Germany & 2 & 2 & 2 & 100 & 99 & 84 \\
\hline France, Monaco & 3 & 3 & 3 & 113 & 114 & 105 \\
\hline UK & 4 & 4 & 5 & 97 & 104 & 110 \\
\hline Italy & 5 & 5 & 4 & 114 & 123 & 107 \\
\hline Japan & 6 & 6 & 7 & 160 & 159 & 151 \\
\hline Spain & 8 & 7 & 8 & 118 & 111 & 102 \\
\hline Belgium-Lux. & 9 & 8 & 9 & 18 & 13 & 14 \\
\hline Netherlands & 7 & 9 & 6 & 31 & 26 & 27 \\
\hline Korea Rep. & 12 & 10 & 12 & 74 & 58 & 51 \\
\hline Canada & 11 & 11 & 11 & 54 & 52 & 53 \\
\hline China & 10 & 12 & 10 & 57 & 90 & 73 \\
\hline Taiwan & 13 & 13 & 13 & 29 & 33 & NA \\
\hline Russian Fed & 168 & 14 & 15 & 152 & 116 & 66 \\
\hline China HK SAR & 16 & 15 & 17 & 10 & 8 & 8 \\
\hline Thailand & 15 & 16 & 14 & 39 & 36 & 19 \\
\hline Singapore & 14 & 17 & 16 & 5 & 4 & 4 \\
\hline Turkey & 23 & 18 & 18 & 125 & 115 & 111 \\
\hline Brazil & 22 & 19 & 19 & 158 & 162 & 150 \\
\hline India & 20 & 20 & 20 & 155 & 155 & 165 \\
\hline Portugal & 17 & 21 & 22 & 70 & 70 & 69 \\
\hline Switz.Liecht & 18 & 22 & 21 & 58 & 54 & 55 \\
\hline Austria & 21 & 23 & 24 & 68 & 61 & 63 \\
\hline Malaysia & 27 & 24 & 27 & 8 & 7 & 6 \\
\hline Poland & 26 & 25 & 25 & 104 & 96 & 96 \\
\hline Australia & 24 & 26 & 28 & 130 & 140 & 124 \\
\hline Indonesia & 32 & 27 & 30 & 86 & 89 & 57 \\
\hline Sweden & 19 & 28 & 26 & 66 & 56 & 61 \\
\hline Greece & 30 & 29 & 29 & 127 & 138 & 121 \\
\hline Mexico & 25 & 30 & 23 & 115 & 68 & 67 \\
\hline Philippines & 39 & 31 & 31 & 49 & 35 & 23 \\
\hline Norway & 33 & 32 & 34 & 69 & 67 & 76 \\
\hline Denmark & 28 & 33 & 32 & 80 & 77 & 80 \\
\hline Finland & 29 & 34 & 41 & 65 & 59 & 58 \\
\hline Iran & 59 & 35 & 42 & 144 & 135 & 114 \\
\hline Venezuela & 47 & 48 & 43 & 96 & 105 & 115 \\
\hline Argentina & 44 & 46 & 51 & 159 & 156 & 156 \\
\hline
\end{tabular}

Note: Countries ranked according to 1997 node centrality results at the one percent threshold. The columns for Total Trade to GDP show how these countries rank in this category. 
Table 2. Rankings for the Top Thirty Five Countries According to Node Importance Index

\begin{tabular}{|c|c|c|c|c|c|c|}
\hline & \multicolumn{3}{|c|}{ Node Importance (IV: World Trade Share) } & \multicolumn{3}{|c|}{ Total Trade (Exports plus Imports) to GDP } \\
\hline & 1994 & 1997 & 2000 & 1994 & 1997 & 2000 \\
\hline USA & 1 & 1 & 1 & 156 & 154 & 148 \\
\hline Germany & 2 & 2 & 2 & 100 & 99 & 84 \\
\hline France,Monac & 3 & 3 & 3 & 113 & 114 & 105 \\
\hline UK & 4 & 4 & 5 & 97 & 104 & 110 \\
\hline Italy & 5 & 5 & 4 & 114 & 123 & 107 \\
\hline Japan & 6 & 6 & 7 & 160 & 159 & 151 \\
\hline Spain & 8 & 7 & 8 & 118 & 111 & 102 \\
\hline Belgium-Lux & 9 & 8 & 8 & 18 & 13 & 14 \\
\hline Netherlands & 7 & 8 & 6 & 31 & 26 & 27 \\
\hline Korea Rep. & 12 & 9 & 11 & 74 & 58 & 51 \\
\hline Canada & 11 & 10 & 10 & 54 & 52 & 53 \\
\hline China & 10 & 10 & 9 & 57 & 90 & 73 \\
\hline Taiwan & 13 & 11 & 12 & 29 & 33 & NA \\
\hline Russian Fed & 46 & 11 & 14 & 152 & 116 & 66 \\
\hline China HK SAR & 16 & 12 & 16 & 10 & 8 & 8 \\
\hline Thailand & 15 & 13 & 13 & 39 & 36 & 19 \\
\hline Singapore & 14 & 14 & 15 & 5 & 4 & 4 \\
\hline Turkey & 22 & 15 & 17 & 125 & 115 & 111 \\
\hline Brazil & 21 & 16 & 18 & 158 & 162 & 150 \\
\hline India & 20 & 17 & 43 & 155 & 155 & 165 \\
\hline Portugal & 17 & 18 & 19 & 70 & 70 & 69 \\
\hline Switz.Liecht & 18 & 19 & 18 & 58 & 54 & 55 \\
\hline Austria & 20 & 20 & 21 & 68 & 61 & 63 \\
\hline Malaysia & 24 & 21 & 23 & 8 & 7 & 6 \\
\hline Poland & 23 & 22 & 22 & 104 & 96 & 96 \\
\hline Australia & 22 & 22 & 23 & 130 & 140 & 124 \\
\hline Indonesia & 28 & 23 & 24 & 86 & 89 & 57 \\
\hline Sweden & 19 & 24 & 22 & 66 & 56 & 61 \\
\hline Greece & 27 & 25 & 23 & 127 & 138 & 121 \\
\hline Mexico & 23 & 26 & 20 & 115 & 68 & 67 \\
\hline Philippines & 33 & 26 & 25 & 49 & 35 & 23 \\
\hline Norway & 29 & 26 & 27 & 69 & 67 & 76 \\
\hline Denmark & 25 & 27 & 25 & 80 & 77 & 80 \\
\hline Finland & 26 & 28 & 31 & 65 & 59 & 58 \\
\hline Iran & 43 & 29 & 31 & 144 & 135 & 114 \\
\hline South Africa & 31 & 30 & 31 & 123 & 107 & 99 \\
\hline Czech Rep & 32 & 30 & 28 & 43 & 31 & 22 \\
\hline Hungary & 30 & 31 & 28 & 50 & 30 & 13 \\
\hline Saudi Arabia & 28 & 32 & 26 & 51 & 65 & 79 \\
\hline Romania & 35 & 32 & 30 & 92 & 63 & 64 \\
\hline Israel & 33 & 33 & 28 & 79 & 91 & 83 \\
\hline Chile & 34 & 34 & 33 & 93 & 103 & 98 \\
\hline Pakistan & 32 & 34 & 29 & 131 & 139 & 128 \\
\hline Bulgaria & 44 & 35 & 35 & 60 & 25 & 31 \\
\hline Venezuela & 38 & 37 & 31 & 96 & 105 & 115 \\
\hline Argentina & 37 & 36 & 36 & 159 & 156 & 156 \\
\hline
\end{tabular}

Note: Countries ranked according to 1997 node importance results using world trade share as the Intrinsic Value (IV). The columns for Total Trade to GDP show how these countries rank in this category. 
Table 3. Rankings for the Top Thirty Countries According to Maximum Flow Measure

\begin{tabular}{|c|c|c|c|c|c|c|}
\hline & \multicolumn{3}{|c|}{ Maximum Flow (one percent threshold) } & \multicolumn{3}{|c|}{ Total Trade (Exports plus Imports) to GDP } \\
\hline & 1994 & 1997 & 2000 & 1994 & 1997 & 2000 \\
\hline Canada & 1 & 1 & 1 & 54 & 52 & 53 \\
\hline China & 2 & 2 & 4 & 57 & 90 & 73 \\
\hline Netherlands & 4 & 3 & 3 & 31 & 26 & 27 \\
\hline Belgium-Lux & 4 & 4 & 3 & 18 & 13 & 14 \\
\hline Spain & 6 & 4 & 5 & 118 & 111 & 102 \\
\hline Japan & 8 & 5 & 8 & 160 & 159 & 151 \\
\hline China HK SAR & 7 & 5 & 9 & 10 & 8 & 8 \\
\hline Taiwan & 6 & 5 & 6 & 29 & 33 & NA \\
\hline Singapore & 9 & 6 & 6 & 5 & 4 & 4 \\
\hline France,Monac & 3 & 6 & 4 & 113 & 114 & 105 \\
\hline Austria & 5 & 6 & 14 & 68 & 61 & 63 \\
\hline Italy & 11 & 7 & 11 & 114 & 123 & 107 \\
\hline USA & 9 & 8 & 8 & 156 & 154 & 148 \\
\hline Turkey & 20 & 8 & 7 & 125 & 115 & 111 \\
\hline Korea Rep. & 10 & 9 & 8 & 74 & 58 & 51 \\
\hline Thailand & 11 & 9 & 12 & 39 & 36 & 19 \\
\hline UK & 10 & 9 & 7 & 97 & 104 & 110 \\
\hline Germany & 6 & 10 & 10 & 100 & 99 & 84 \\
\hline Russian Fed & 52 & 11 & 15 & 152 & 116 & 66 \\
\hline Australia & 13 & 12 & 16 & 130 & 140 & 124 \\
\hline Sweden & 10 & 13 & 9 & 66 & 56 & 61 \\
\hline Poland & 18 & 14 & 13 & 104 & 96 & 96 \\
\hline India & 14 & 15 & 56 & 155 & 155 & 165 \\
\hline Malaysia & 15 & 16 & 17 & 8 & 7 & 6 \\
\hline Brazil & 16 & 17 & 19 & 158 & 162 & 150 \\
\hline Switz.Liecht & 12 & 18 & 11 & 58 & 54 & 55 \\
\hline Philippines & 24 & 19 & 18 & 49 & 35 & 23 \\
\hline Mexico & 17 & 20 & 2 & 115 & 68 & 67 \\
\hline Indonesia & 21 & 21 & 23 & 86 & 89 & 57 \\
\hline Denmark & 19 & 22 & 20 & 80 & 77 & 80 \\
\hline Saudi Arabia & 23 & 23 & 33 & 51 & 65 & 79 \\
\hline Portugal & 22 & 24 & 22 & 70 & 70 & 69 \\
\hline Czech Rep & 33 & 25 & 25 & 43 & 31 & 22 \\
\hline Israel & 25 & 26 & 27 & 79 & 91 & 83 \\
\hline Greece & 26 & 27 & 21 & 127 & 138 & 121 \\
\hline Romania & 34 & 28 & 29 & 92 & 63 & 64 \\
\hline Hungary & 31 & 29 & 24 & 50 & 30 & 13 \\
\hline Chile & 25 & 30 & 31 & 93 & 103 & 98 \\
\hline Venezuela & 39 & 38 & 32 & 96 & 105 & 115 \\
\hline Argentina & 27 & 36 & 35 & 159 & 156 & 156 \\
\hline
\end{tabular}

Note: Countries ranked according to 1997 maximum flow results at the one percent threshold. The columns for Total Trade to GDP show how these countries rank in this category. 


\section{Table 4. Top Thirty Five Countries Affected by Shocks to Source Country According to Maximum Flow Measure.}

\begin{tabular}{|c|c|c|c|c|c|c|c|c|c|c|c|c|}
\hline \multirow{2}{*}{\multicolumn{3}{|c|}{ Mexico (1994) }} & \multicolumn{4}{|c|}{$S O U R C E$} & \multicolumn{6}{|c|}{ COUNTRY } \\
\hline & & & \multicolumn{2}{|c|}{ Venezuela (1995) } & \multicolumn{2}{|c|}{ Thailand (1997) } & \multicolumn{2}{|c|}{ Russia (1998) } & \multicolumn{2}{|c|}{ Argentina (2000) } & \multicolumn{2}{|c|}{ Brazil (1998) } \\
\hline & Bahamas & 16 & Bahamas & 8 & Brazil & 24 & "Jordan & 25 & Chile & 8 & Chile & 22 \\
\hline & Cuba & 16 & Cuba & 8 & India & 24 & Korea Rep. & 24 & Peru & 8 & Argentina & 20 \\
\hline & Mali & 16 & Mali & 8 & Jordan & 24 & India & 23 & Ecuador & 8 & Peru & 20 \\
\hline \multirow[b]{2}{*}{$A$} & Togo & 16 & Togo & 8 & Russian Fed & 24 & South Africa & 23 & Panama & 8 & Ecuador & 20 \\
\hline & Algeria & 15 & Algeria & 8 & South Africa & 24 & Saudi Arabia & 23 & Mali & 8 & Panama & 20 \\
\hline \multirow{2}{*}{$\boldsymbol{F}$} & Argentina & 15 & Argentina & 8 & Germany & 23 & Brazil & 22 & Jordan & 8 & Mali & 19 \\
\hline & Australia & 15 & Australia & 8 & Iran & 23 & Chile & 22 & Korea Rep. & 8 & Jordan & 18 \\
\hline \multirow[t]{2}{*}{$\boldsymbol{F}$} & Austria & 15 & Austria & 8 & Sweden & 23 & Pakistan & 22 & India & 8 & Korea Rep. & 18 \\
\hline & Azerbaijan & 15 & Azerbaijan & 8 & Argentina & 22 & Germany & 21 & South Africa & 8 & India & 18 \\
\hline \multirow[t]{2}{*}{$\boldsymbol{E}$} & Bahrain & 15 & Bahrain & 8 & Chile & 22 & Sweden & 21 & Saudi Arabia & 8 & South Africa & 18 \\
\hline & Belarus & 15 & Belarus & 8 & Egypt & 22 & Finland & 21 & Pakistan & 8 & Saudi Arabia & 18 \\
\hline \multirow[t]{2}{*}{ C } & Brazil & 15 & Brazil & 8 & Finland & 22 & Indonesia & 21 & Germany & 8 & Pakistan & 18 \\
\hline & Bulgaria & 15 & Bulgaria & 8 & Korea Rep. & 21 & Greece & 21 & Sweden & 8 & Germany & 18 \\
\hline$T$ & Burundi & 15 & Burundi & 8 & New Zealand & 21 & Iran & 20 & Finland & 8 & Sweden & 18 \\
\hline \multirow{2}{*}{$E$} & Chile & 15 & Chile & 8 & Pakistan & 21 & Argentina & 20 & Indonesia & 8 & Finland & 18 \\
\hline & China HK SAR & 15 & China HK SAR & 8 & Peru & 21 & New Zealand & 20 & Greece & 8 & Indonesia & 18 \\
\hline \multirow[t]{4}{*}{$D$} & Colombia & 15 & Colombia & 8 & UK & 21 & Peru & 20 & Iran & 8 & Greece & 18 \\
\hline & Cyprus & 15 & Cyprus & 8 & Ukraine & 21 & UK & 20 & New Zealand & 8 & Iran & 18 \\
\hline & Denmark & 15 & Denmark & 8 & Sudan & 21 & Ukraine & 20 & UK & 8 & New Zealand & 18 \\
\hline & Ecuador & 15 & Ecuador & 8 & Togo & 20 & Viet Nam & 20 & Ukraine & 8 & UK & 18 \\
\hline$C$ & Egypt & 15 & Egypt & 8 & Indonesia & 20 & Australia & 20 & Viet Nam & 8 & Ukraine & 18 \\
\hline \multirow{2}{*}{$\boldsymbol{O}$} & Estonia & 15 & Estonia & 8 & Israel & 20 & Ecuador & 20 & Australia & 8 & Viet Nam & 18 \\
\hline & Finland & 15 & Finland & 8 & Saudi Arabia & 20 & Panama & 20 & Japan & 8 & Australia & 18 \\
\hline \multirow{2}{*}{$U$} & Germany & 15 & Germany & 8 & Switz.Liecht & 20 & Japan & 20 & Israel & 8 & Japan & 18 \\
\hline & Greece & 15 & Greece & 8 & Tanzania & 20 & Israel & 19 & Switz.Liecht & 8 & Israel & 18 \\
\hline \multirow[t]{2}{*}{$N$} & Hungary & 15 & Hungary & 8 & Turkey & 20 & Switz.Liecht & 19 & Austria & 8 & Switz.Liecht & 18 \\
\hline & Iceland & 15 & Iceland & 8 & USA & 20 & Mali & 19 & Zimbabwe & 8 & Austria & 18 \\
\hline \multirow[t]{2}{*}{$T$} & India & 15 & India & 8 & Viet Nam & 20 & Austria & 19 & Tajikistan & 8 & Zimbabwe & 18 \\
\hline & Indonesia & 15 & Indonesia & 8 & Australia & 19 & Zimbabwe & 19 & Zambia & 8 & Tajikistan & 18 \\
\hline \multirow[t]{2}{*}{$\boldsymbol{R}$} & Iran & 15 & Iran & 8 & Bahrain & 19 & Tajikistan & 19 & Iraq & 8 & Zambia & 18 \\
\hline & Israel & 15 & Israel & 8 & Colombia & 19 & Zambia & 19 & Thailand & 8 & Iraq & 18 \\
\hline \multirow[t]{4}{*}{$Y$} & Italy & 15 & Italy & 8 & Ecuador & 19 & Iraq & 19 & Egypt & 8 & Thailand & 18 \\
\hline & Japan & 15 & Japan & 8 & Greece & 19 & Thailand & 19 & Togo & 8 & Egypt & 18 \\
\hline & Jordan & 15 & Jordan & 8 & Italy & 19 & Egypt & 18 & Tanzania & 8 & Togo & 18 \\
\hline & Kazakhstan & 15 & Kazakhstan & 8 & Malawi & 19 & Togo & 18 & USA & 8 & Tanzania & 18 \\
\hline
\end{tabular}

\section{Table 5. List of Country Crises (Windows Crisis)}

\begin{tabular}{|c|c|c|c|}
\hline \multicolumn{2}{|r|}{ Forbes (2001) } & \multicolumn{2}{|c|}{ Glick and Rose (1998) } \\
\hline \multirow{2}{*}{ Mexico } & 12/19/94 - 12/25/94; 01/16/95 - 01/29/95; 02/27/95 - 03/05/95; & Bretton Woods Collapse & 1971 \\
\hline & 03/13/95 - 03/19/95 & Collapse of Smithsonian Agreement & 1973 (Winter) \\
\hline Ecuador (1) & 01/23/95 - 02/12/95; 10/30/95- 11/05/95 & EMS Crisis & $1992-1993$ \\
\hline Argentina & 03/06/95 - 03/12/95 & Mexican Meltdown (Tequila Effect) & $1994-1995$ \\
\hline Venezuela (1) & $12 / 11 / 95$ - 12/17/95; 04/15/96 - 04/12/96 & Asian Flu & $1997-1998$ \\
\hline Venezuela (2) & $05 / 12 / 97-05 / 18 / 97$ & & \\
\hline Czech Republic & $05 / 19 / 97-05 / 25 / 97$ & & \\
\hline Thailand & 06/30/97 - 07/06/97 & \multicolumn{2}{|c|}{ Rigobon (2003) } \\
\hline Philippines & 07/07/97 - 07/13/97; 09/29/97 - 10/05/97 & Mexican Crisis & $12 / 19 / 94-3 / 31 / 95$ \\
\hline & 08/11/97 - 08/17/97; 08/25/97 - 08/31/97; 09/29/97 - 10/05/97; & Asian Crisis (Thailand) & $6 / 10 / 97-1 / 30 / 98$ \\
\hline Indonesia & $\begin{array}{c}\text { 12/08/97 - 12/14/97; 01/19/98 - 01/25/98; 03/02/98 - 03/08/98; } \\
05 / 18 / 98 \text { - 05//24/98 }\end{array}$ & Russian Crisis & 8/3/98 - 11/23/98 \\
\hline Korea & $12 / 29 / 97-01 / 04 / 98$ & & \\
\hline India & $01 / 19 / 98-01 / 25 / 98$ & & \\
\hline \multirow{2}{*}{ Russia } & 05/18/98 - 05/31/98; 07/06/98 - 07/12/98; 08/10/98 - 09/06/98; & \multicolumn{2}{|c|}{ Kali and Reyes (2005) } \\
\hline & $09 / 14 / 98-09 / 20 / 98$ & $\begin{array}{l}\text { Mexican Crisis (Tequila Crisis) } \\
\end{array}$ & $12 / 24 / 94-03 / 18 / 95$ \\
\hline Venezuela & 06/15/98 - 06/21/98; 09/14/98 - 09/20/98 & Venezuela Crisis & $12 / 16 / 95-04 / 20 / 96$ \\
\hline Slovak Republic & $09 / 28 / 98-10 / 04 / 98$ & Thailand Crisis (Asian Flu) & 07/05/97 - 01/03/98 \\
\hline Ecuador (2) & 10/19/98 - 10/25/98; 1/11/99 - 1/17/99; 03/01/99 - 03/07/99 & Russian Crisis (Russian Virus) & 05/23/98 - 01/16/99 \\
\hline Brazil & $01 / 11 / 99-01 / 17 / 99$ & Argentinean Crisis & 06/02/01 - 04/06/02 \\
\hline
\end{tabular}


Table 6. Regression Results Using Node Importance and Centrality Indices as the Network Indicators

(Weekly Abnormal Stock Market Returns as the Dependent Variable)

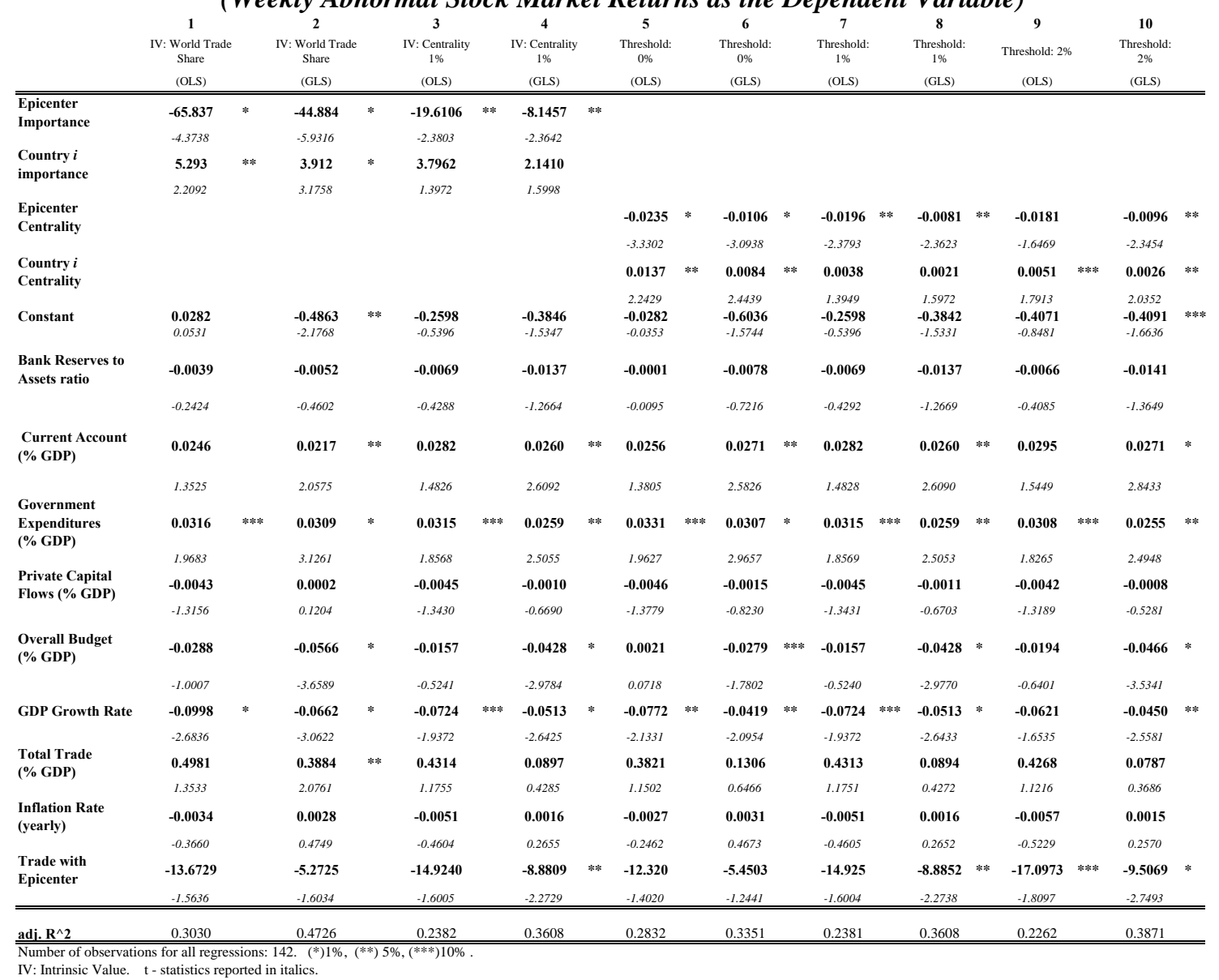

Table 7. Estimated Effects on the Weekly Abnormal Stock Market Return of a One Standard Deviation Increase of the Network Indicator

\begin{tabular}{|c|c|c|c|c|c|c|}
\hline & \multicolumn{2}{|c|}{ Effects in terms of standard deviations } & \multicolumn{2}{|c|}{ Effects in terms of percentage points } & \multicolumn{2}{|c|}{ Accumulated effects over a period of ten weeks (\%) } \\
\hline & OLS & GLS & OLS & GLS & OLS & GLS \\
\hline $\begin{array}{l}\text { Epicenter Importance } \\
\text { (IV: world trade share) }\end{array}$ & -0.275 & -0.187 & -0.351 & -0.239 & -3.509 & -2.392 \\
\hline $\begin{array}{l}\text { Country i importance } \\
\text { (IV: world trade share) }\end{array}$ & 0.114 & 0.084 & 0.146 & 0.108 & 1.455 & 1.076 \\
\hline $\begin{array}{l}\text { Epicenter Importance } \\
\text { (IV: centrality 1\%) }\end{array}$ & -0.171 & -0.071 & -0.218 & -0.091 & -2.180 & -0.906 \\
\hline $\begin{array}{l}\text { Country i importance } \\
\text { (IV: centrality } 1 \% \text { ) }\end{array}$ & 0.077 & 0.043 & 0.098 & 0.055 & 0.979 & 0.552 \\
\hline $\begin{array}{l}\text { Epicenter Centrality } \\
\text { (0\% threshold) }\end{array}$ & -0.239 & -0.108 & -0.305 & -0.137 & -3.051 & -1.373 \\
\hline $\begin{array}{l}\text { Country i Centrality } \\
\text { ( } 0 \% \text { threshold) }\end{array}$ & 0.177 & 0.108 & 0.226 & 0.138 & 2.256 & 1.380 \\
\hline $\begin{array}{l}\text { Epicenter Centrality } \\
\text { (1\% threshold) }\end{array}$ & -0.171 & -0.071 & -0.218 & -0.091 & -2.180 & -0.905 \\
\hline $\begin{array}{l}\text { Country i Centrality } \\
\text { (1\% threshold) }\end{array}$ & 0.077 & 0.043 & 0.098 & 0.055 & 0.978 & 0.552 \\
\hline $\begin{array}{l}\text { Epicenter Centrality } \\
\text { ( } 2 \% \text { threshold) }\end{array}$ & -0.116 & -0.061 & -0.148 & -0.078 & -1.475 & -0.783 \\
\hline $\begin{array}{l}\text { Country i Centrality } \\
\text { ( } 2 \% \text { threshold) }\end{array}$ & 0.088 & 0.044 & 0.113 & 0.057 & 1.129 & 0.566 \\
\hline
\end{tabular}


Table 8. Epicenter and Country $i$ Effects for the Five Crisis Windows Considered using the Estimated Coefficients in Table 5

(in percentage points of weekly abnormal stock market returns)

\begin{tabular}{|c|c|c|c|c|}
\hline \multirow{4}{*}{$\begin{array}{c}\text { Mexican Crisis } \\
\text { Epicenter Country }\end{array}$} & \multicolumn{2}{|c|}{$\begin{array}{l}\text { Node Importance } \\
\end{array}$} & \multicolumn{2}{|c|}{ Node Centrality } \\
\hline & IV: World Trade Share & IV: Node Centrality $1 \%$ & $1 \%$ threshold & $2 \%$ threshold \\
\hline & & & & \\
\hline & -0.759 & -0.131 & -0.131 & -0.077 \\
\hline Brazil & 0.038 & 0.042 & 0.042 & 0.041 \\
\hline Canada & 0.148 & 0.080 & 0.080 & 0.040 \\
\hline Chile & 0.011 & 0.018 & 0.018 & 0.012 \\
\hline Ecuador & 0.004 & 0.005 & 0.005 & 0.003 \\
\hline Greece & 0.014 & 0.030 & 0.030 & 0.016 \\
\hline India & 0.027 & 0.044 & 0.044 & 0.038 \\
\hline Indonesia & 0.036 & 0.027 & 0.027 & 0.015 \\
\hline Italy & 0.162 & 0.165 & 0.165 & 0.152 \\
\hline Korea & 0.091 & 0.078 & 0.078 & 0.063 \\
\hline Malaysia & 0.059 & 0.033 & 0.033 & 0.031 \\
\hline Mexico & 0.066 & 0.034 & 0.034 & 0.021 \\
\hline Russia & - & - & - & - \\
\hline Thailand & 0.046 & 0.057 & 0.057 & 0.043 \\
\hline United States & 0.576 & 0.190 & 0.190 & 0.210 \\
\hline Venezuela & 0.011 & 0.011 & 0.011 & 0.006 \\
\hline Venezuelan $\mathrm{Cr}$ & & & & \\
\hline Epicenter Country & -0.133 & -0.047 & -0.047 & -0.033 \\
\hline Brazil & 0.041 & 0.054 & 0.054 & 0.044 \\
\hline Canada & 0.141 & 0.076 & 0.076 & 0.034 \\
\hline Chile & 0.012 & 0.017 & 0.017 & 0.010 \\
\hline Ecuador & 0.004 & 0.005 & 0.005 & 0.003 \\
\hline Greece & 0.014 & 0.033 & 0.033 & 0.019 \\
\hline India & 0.028 & 0.052 & 0.052 & 0.034 \\
\hline Indonesia & 0.036 & 0.038 & 0.038 & 0.019 \\
\hline Italy & 0.165 & 0.158 & 0.158 & 0.150 \\
\hline Korea & 0.099 & 0.083 & 0.082 & 0.066 \\
\hline Malaysia & 0.063 & 0.037 & 0.037 & 0.028 \\
\hline Mexico & 0.059 & 0.015 & 0.015 & 0.007 \\
\hline Russia & 0.026 & 0.000 & 0.000 & 0.000 \\
\hline Thailand & 0.049 & 0.064 & 0.064 & 0.043 \\
\hline United States & 0.549 & 0.196 & 0.196 & 0.210 \\
\hline Venezuela & 0.012 & 0.012 & 0.012 & 0.009 \\
\hline Asian Crisis & & & & \\
\hline Epicenter Country & -0.505 & -0.234 & -0.234 & -0.171 \\
\hline Brazil & 0.043 & 0.053 & 0.053 & 0.029 \\
\hline Canada & 0.147 & 0.083 & 0.082 & 0.035 \\
\hline Chile & 0.013 & 0.016 & 0.016 & 0.010 \\
\hline Ecuador & 0.004 & 0.005 & 0.005 & 0.004 \\
\hline Greece & 0.013 & 0.033 & 0.033 & 0.019 \\
\hline India & 0.029 & 0.050 & 0.050 & 0.040 \\
\hline Indonesia & 0.037 & 0.036 & 0.036 & 0.016 \\
\hline Italy & 0.155 & 0.153 & 0.153 & 0.145 \\
\hline Korea & 0.098 & 0.084 & 0.084 & 0.067 \\
\hline Malaysia & 0.061 & 0.039 & 0.039 & 0.028 \\
\hline Mexico & 0.078 & 0.030 & 0.030 & 0.015 \\
\hline Russia & 0.056 & 0.073 & 0.073 & 0.062 \\
\hline Thailand & 0.044 & 0.062 & 0.062 & 0.045 \\
\hline United States & 0.582 & 0.194 & 0.193 & 0.211 \\
\hline Venezuela & 0.013 & 0.011 & 0.011 & 0.007 \\
\hline Russian Cris & & & & \\
\hline Epicenter Country & -0.562 & -0.248 & -0.248 & -0.220 \\
\hline Brazil & 0.042 & 0.037 & 0.037 & 0.025 \\
\hline Canada & 0.152 & 0.087 & 0.087 & 0.041 \\
\hline Chile & 0.012 & 0.016 & 0.016 & 0.013 \\
\hline Ecuador & 0.004 & 0.012 & 0.012 & 0.004 \\
\hline Greece & 0.014 & 0.031 & 0.031 & 0.019 \\
\hline India & 0.029 & 0.050 & 0.050 & 0.041 \\
\hline Indonesia & 0.031 & 0.027 & 0.027 & 0.018 \\
\hline Italy & 0.161 & 0.156 & 0.156 & 0.145 \\
\hline Korea & 0.080 & 0.066 & 0.066 & 0.054 \\
\hline Malaysia & 0.052 & 0.031 & 0.031 & 0.022 \\
\hline Mexico & 0.087 & 0.030 & 0.030 & 0.010 \\
\hline Russia & 0.049 & 0.065 & 0.065 & 0.059 \\
\hline Thailand & 0.036 & 0.049 & 0.049 & 0.034 \\
\hline United States & 0.603 & 0.195 & 0.194 & 0.214 \\
\hline Venezuela & 0.012 & 0.018 & 0.018 & 0.009 \\
\hline Argentinean $\mathrm{C}$ & & & & \\
\hline Epicenter Country & -0.175 & -0.033 & -0.033 & -0.022 \\
\hline Brazil & 0.037 & 0.047 & 0.047 & 0.029 \\
\hline Canada & 0.161 & 0.084 & 0.084 & 0.041 \\
\hline Chile & 0.011 & 0.014 & 0.014 & 0.010 \\
\hline Ecuador & 0.003 & 0.005 & 0.005 & 0.003 \\
\hline Greece & 0.012 & 0.034 & 0.034 & 0.022 \\
\hline India & 0.031 & 0.060 & 0.060 & 0.047 \\
\hline Indonesia & 0.032 & 0.033 & 0.033 & 0.018 \\
\hline Italy & 0.143 & 0.161 & 0.161 & 0.144 \\
\hline Korea & 0.105 & 0.074 & 0.074 & 0.067 \\
\hline Malaysia & 0.061 & 0.034 & 0.034 & 0.028 \\
\hline Mexico & 0.110 & 0.038 & 0.038 & 0.023 \\
\hline Russia & 0.049 & 0.058 & 0.058 & 0.048 \\
\hline Thailand & 0.042 & 0.059 & 0.059 & 0.037 \\
\hline United States & 0.633 & 0.201 & 0.201 & 0.226 \\
\hline Venezuela & 0.014 & 0.016 & 0.016 & 0.010 \\
\hline
\end{tabular}


Table 9. Regression Results using the Maximum Flow Measure as the Network Indicator

(Weekly Abnormal Stock Market Returns as the Dependent Variable)

\begin{tabular}{|c|c|c|c|c|c|c|c|c|c|c|c|c|c|c|c|c|}
\hline & $\begin{array}{c}\mathbf{1} \\
\text { Threshold } \\
0 \% \\
\text { (OLS) }\end{array}$ & & $\begin{array}{c}\mathbf{2} \\
\text { Threshold } \\
0 \% \\
\text { (GLS) }\end{array}$ & & $\begin{array}{c}\mathbf{3} \\
\text { Threshold } \\
0.5 \% \\
\text { (OLS) }\end{array}$ & & $\begin{array}{c}\mathbf{4} \\
\text { Threshold } \\
0.5 \% \\
\text { (GLS) }\end{array}$ & & $\begin{array}{c}\mathbf{5} \\
\text { Threshold } \\
1 \% \\
\text { (OLS) }\end{array}$ & & $\begin{array}{c}\mathbf{6} \\
\text { Threshold } \\
1 \% \\
\text { (GLS) }\end{array}$ & & $\begin{array}{c}7 \\
\text { Threshold } \\
2 \% \\
\text { (OLS) }\end{array}$ & & $\begin{array}{c}\mathbf{8} \\
\text { Threshold } \\
2 \% \\
\text { (GLS) }\end{array}$ & \\
\hline Maximum Flow $e$ to $i$ & 0.0003 & & -0.0018 & & -0.0106 & & -0.0085 & $* * *$ & -0.0241 & & -0.0143 & ** & -0.0351 & & -0.0112 & \\
\hline & 0.0402 & & -0.9747 & & -0.6239 & & -1.9512 & & -0.8496 & & -2.1535 & & -1.0448 & & -1.2733 & \\
\hline Constant & $\begin{array}{l}\mathbf{- 1 . 5 0 9 2} \\
-1.1856\end{array}$ & & $\begin{array}{l}\mathbf{- 1 . 0 6 1 6} \\
-4.0477\end{array}$ & * & $\begin{array}{l}-\mathbf{- 1 . 2 3 6 5} \\
-1.2611\end{array}$ & & $\begin{array}{l}\mathbf{- 0 . 9 4 9 0} \\
-5.1682\end{array}$ & * & $\begin{array}{l}-\mathbf{- 1 . 1 1 7 5} \\
-1.1138\end{array}$ & & $\begin{array}{l}\mathbf{- 0 . 9 7 0 8} \\
-5.2713\end{array}$ & * & $\begin{array}{l}-\mathbf{1 . 2 8 8 5} \\
-1.6384\end{array}$ & & $\begin{array}{l}-\mathbf{1 . 2 2 1 2} \\
-9.7512\end{array}$ & * \\
\hline $\begin{array}{l}\text { Bank Reserves to } \\
\text { Assets ratio }\end{array}$ & $\begin{array}{c}\mathbf{0 . 0 0 2 3} \\
0.1308\end{array}$ & & $\begin{array}{l}-\mathbf{- 0 . 0 0 2 2} \\
-0.1870\end{array}$ & & $\begin{array}{l}\mathbf{0 . 0 0 3 4} \\
0.1942\end{array}$ & & $\begin{array}{c}-\mathbf{0 . 0 0 3 4} \\
-0.2939\end{array}$ & & $\begin{array}{l}\mathbf{0 . 0 0 3 5} \\
0.2012\end{array}$ & & $\begin{array}{l}-\mathbf{0 . 0 0 4 5} \\
-0.3973\end{array}$ & & $\begin{array}{c}\mathbf{0 . 0 0 3 1} \\
0.1778\end{array}$ & & $\begin{array}{c}-\mathbf{0 . 0 0 6 0} \\
-0.5293\end{array}$ & \\
\hline $\begin{array}{l}\text { Current Account } \\
\text { (\% GDP) }\end{array}$ & $\begin{array}{l}\mathbf{0 . 0 5 0 9} \\
2.4486\end{array}$ & ** & $\begin{array}{l}\mathbf{0 . 0 4 4 5} \\
4.8450\end{array}$ & * & $\begin{array}{l}\mathbf{0 . 0 5 2 3} \\
2.4500\end{array}$ & $* *$ & $\begin{array}{l}\mathbf{0 . 0 4 2 4} \\
4.7344\end{array}$ & * & $\begin{array}{l}\mathbf{0 . 0 4 9 8} \\
2.1637\end{array}$ & ** & $\begin{array}{l}\mathbf{0 . 0 3 9 8} \\
4.2798\end{array}$ & * & $\begin{array}{l}\mathbf{0 . 0 4 9 3} \\
2.1455\end{array}$ & ** & $\begin{array}{l}\mathbf{0 . 0 4 2 0} \\
4.5953\end{array}$ & * \\
\hline $\begin{array}{l}\text { Government } \\
\text { Expenditures }\end{array}$ & 0.0510 & * & 0.0419 & * & 0.0528 & ** & 0.0391 & * & 0.0519 & ** & 0.0393 & * & 0.0517 & ** & 0.0405 & $*$ \\
\hline & 2.6370 & & 4.8385 & & 2.5231 & & 4.5036 & & 2.3819 & & 4.4502 & & 2.3644 & & 4.7101 & \\
\hline $\begin{array}{l}\text { Private Capital Flows } \\
\text { (\% GDP) }\end{array}$ & $\begin{array}{c}-\mathbf{0 . 0 0 0 1} \\
-0.0324\end{array}$ & & $\begin{array}{l}\mathbf{0 . 0 0 1 6} \\
1.3204\end{array}$ & & $\begin{array}{l}\mathbf{0 . 0 0 0 0} \\
0.0054\end{array}$ & & $\begin{array}{l}\mathbf{0 . 0 0 1 9} \\
1.2609\end{array}$ & & $\begin{array}{l}\mathbf{0 . 0 0 0 0} \\
-0.0123\end{array}$ & & 0.0018 & & $\begin{array}{l}\mathbf{0 . 0 0 0 0} \\
-0.0124\end{array}$ & & 0.0019 & \\
\hline $\begin{array}{l}\text { Overall Budget } \\
\text { (\% GDP) }\end{array}$ & $\begin{array}{c}-\mathbf{0 . 0 6 0 9} \\
-1.6749\end{array}$ & $* * *$ & $\begin{array}{l}-\mathbf{0 . 0 7 8 1} \\
-5.6444\end{array}$ & * & $\begin{array}{c}-\mathbf{0 . 0 6 1 9} \\
-1.7317\end{array}$ & $* * *$ & $\begin{array}{c}-\mathbf{0 . 0 7 4 0} \\
-5.4666\end{array}$ & * & $\begin{array}{c}-\mathbf{0 . 0 5 7 7} \\
-1.5102\end{array}$ & & $\begin{array}{l}-\mathbf{0 . 0 7 1 1} \\
-5.1946\end{array}$ & * & $\begin{array}{c}-\mathbf{0 . 0 5 5 8} \\
-1.4463\end{array}$ & & $\begin{array}{l}-\mathbf{0 . 0 7 6 8} \\
-5.7897\end{array}$ & * \\
\hline GDP Growth Rate & $\begin{array}{l}-\mathbf{- 0 . 0 6 0 4} \\
-1.3840\end{array}$ & & $\begin{array}{l}-\mathbf{0 . 0 4 6 4} \\
-2.4114\end{array}$ & ** & $\begin{array}{l}-\mathbf{0 . 0 6 2 7} \\
-1.2472\end{array}$ & & $\begin{array}{l}-\mathbf{0 . 0 4 8 0} \\
-2.4619\end{array}$ & ** & $\begin{array}{l}-\mathbf{0 . 0 6 3 0} \\
-1.2662\end{array}$ & & $\begin{array}{l}-\mathbf{0 . 0 4 4 7} \\
-2.3238\end{array}$ & ** & $\begin{array}{l}-\mathbf{0 . 0 6 1 5} \\
-1.2712\end{array}$ & & $\begin{array}{l}-\mathbf{- 0 . 0 3 7 1} \\
-1.8657\end{array}$ & $* * *$ \\
\hline $\begin{array}{l}\text { Total Trade } \\
\text { (\% GDP) }\end{array}$ & $\begin{array}{c}\mathbf{0 . 6 5 5 4} \\
1.7051\end{array}$ & $* * *$ & $\begin{array}{l}\mathbf{0 . 4 3 7 0} \\
2.4997\end{array}$ & ** & $\begin{array}{l}\mathbf{0 . 6 0 2 7} \\
1.4779\end{array}$ & & $\begin{array}{l}\mathbf{0 . 2 9 5 5} \\
1.7131\end{array}$ & $* * *$ & $\begin{array}{c}\mathbf{0 . 6 0 0 0} \\
1.5155\end{array}$ & & $\begin{array}{l}\mathbf{0 . 3 4 0 4} \\
2.0349\end{array}$ & ** & $\begin{array}{l}\mathbf{0 . 6 5 0 5} \\
1.7208\end{array}$ & $* * *$ & $\begin{array}{c}\mathbf{0 . 4 3 8 0} \\
2.5411\end{array}$ & $* *$ \\
\hline $\begin{array}{l}\text { Inflation Rate } \\
\text { (yearly) }\end{array}$ & $\begin{array}{c}-\mathbf{0 . 0 0 1 5} \\
-0.1505 \\
\end{array}$ & & $\begin{array}{l}\mathbf{0 . 0 0 1 6} \\
0.2246 \\
\end{array}$ & & $\begin{array}{c}-\mathbf{0 . 0 0 3 1} \\
-0.3187 \\
\end{array}$ & & $\begin{array}{l}\mathbf{0 . 0 0 2 0} \\
0.2817 \\
\end{array}$ & & $\begin{array}{c}-\mathbf{0 . 0 0 3 3} \\
-0.3427 \\
\end{array}$ & & $\begin{array}{l}\mathbf{0 . 0 0 3 0} \\
0.4085 \\
\end{array}$ & & $\begin{array}{c}-\mathbf{0 . 0 0 2 6} \\
-0.2655 \\
\end{array}$ & & $\begin{array}{l}\mathbf{0 . 0 0 4 4} \\
0.5752 \\
\end{array}$ & \\
\hline $\operatorname{adj} \cdot R^{\wedge} 2$ & 0.1379 & & 0.5386 & & 0.1430 & & 0.4843 & & 0.1491 & & 0.5049 & & 0.1474 & & 0.6768 & \\
\hline
\end{tabular}

Table 10. Regression Results for Alternative Specifications Using Node Importance and Centrality Indices as the Network Indicators (Weekly Abnormal Stock Market Returns as the Dependent Variable)

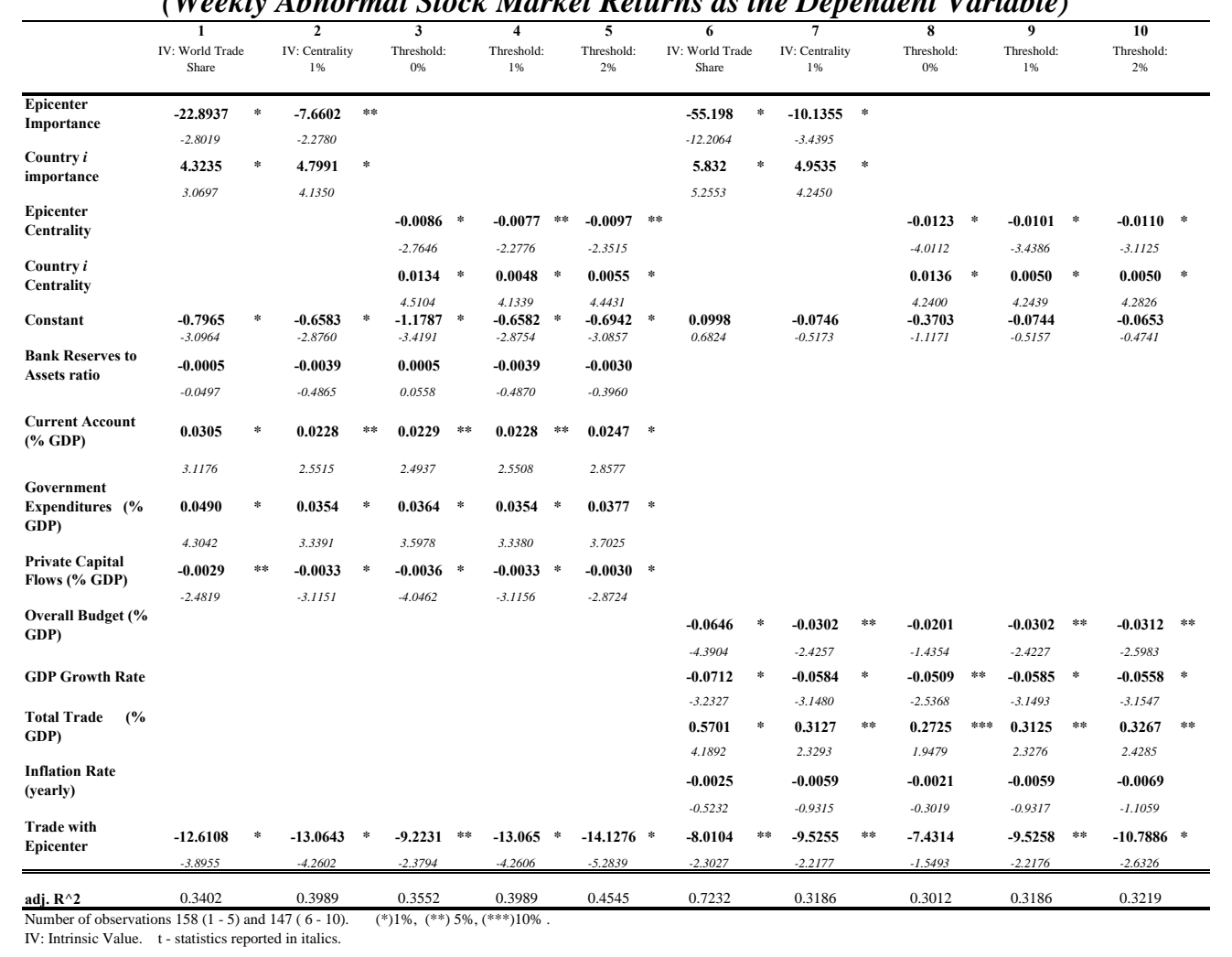


Table 11. Regression Results Using Node Importance and Centrality Indices as the Network Indicators

Panel 1. All Control Variables Included (Alternative definition of Weekly Abnormal Stock Market Returns as the Dependent Variable)

\begin{tabular}{|c|c|c|c|c|c|c|c|c|c|c|c|c|c|c|c|c|c|c|c|c|}
\hline & $\begin{array}{c}1 \\
\text { IV: World Trade } \\
\text { Share } \\
\text { (OLS) } \\
\end{array}$ & & $\begin{array}{c}\mathbf{2} \\
\text { IV: World Trade } \\
\text { Share } \\
\text { (GLS) } \\
\end{array}$ & & $\begin{array}{c}\mathbf{3} \\
\text { IV: Centrality } \\
1 \% \\
\text { (OLS) } \\
\end{array}$ & & $\begin{array}{c}4 \\
\text { IV: Centrality } \\
1 \% \\
\text { (GLS) } \\
\end{array}$ & & $\begin{array}{c}\mathbf{5} \\
\text { Threshold: } \\
0 \% \\
\text { (OLS) } \\
\end{array}$ & & $\begin{array}{c}\mathbf{6} \\
\text { Threshold: } \\
0 \% \\
\text { (GLS) } \\
\end{array}$ & & $\begin{array}{c}7 \\
\text { Threshold: } \\
1 \% \\
\text { (OLS) } \\
\end{array}$ & & $\begin{array}{c}\mathbf{8} \\
\text { Threshold: } \\
1 \% \\
\text { (GLS) } \\
\end{array}$ & & $\begin{array}{c}9 \\
\text { Threshold: } \\
2 \% \\
\text { (OLS) } \\
\end{array}$ & & $\begin{array}{c}10 \\
\text { Threshold: } \\
2 \% \\
\text { (GLS) } \\
\end{array}$ & \\
\hline$\overline{\overline{E p i c e n t e r}}$ & -59.2446 & * & -47.9507 & * & -20.9034 & * & -16.2528 & * & & & & & & & & & & & & \\
\hline 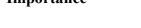 & -4.8567 & & -8.5640 & & -3.3720 & & -4.6569 & & & & & & & & & & & & & \\
\hline $\begin{array}{l}\text { Country } i \\
\text { importance }\end{array}$ & $\begin{array}{l}\mathbf{3 . 5 0 3 0} \\
1.5799\end{array}$ & & $\begin{array}{l}\mathbf{2 . 5 2 0 9} \\
2.4872\end{array}$ & ** & $\begin{array}{l}\mathbf{3 . 0 3 4 2} \\
1.4074\end{array}$ & & $\begin{array}{l}\mathbf{2 . 9 7 5 5} \\
2.8075\end{array}$ & * & & & & & & & & & & & & \\
\hline $\begin{array}{l}\text { Epicenter } \\
\text { Centrality }\end{array}$ & & & & & & & & & $\begin{array}{l}-\mathbf{- 0 . 0 2 2 5} \\
-4.1845\end{array}$ & * & $\begin{array}{l}-\mathbf{- 0 . 0 1 3 8} \\
-4.7715\end{array}$ & * & $\begin{array}{l}-\mathbf{- 0 . 0 2 0 9} \\
-3.3709\end{array}$ & * & $\begin{array}{l}-\mathbf{- 0 . 0 1 6 3} \\
-4.6557\end{array}$ & * & $\begin{array}{l}-\mathbf{0 . 0 2 1 3} \\
-2.5001\end{array}$ & $* *$ & $\begin{array}{l}-\mathbf{0 . 0 1 9 1} \\
-4.4428\end{array}$ & * \\
\hline $\begin{array}{l}\text { Country } i \\
\text { Centrality }\end{array}$ & & & & & & & & & 0.0080 & & 0.0065 & * & 0.0030 & & 0.0030 & * & 0.0039 & **** & 0.0037 & * \\
\hline Constant & $\begin{array}{l}\mathbf{0 . 5 5 1 3} \\
1.2667\end{array}$ & & $\begin{array}{l}\mathbf{0 . 2 5 9 8} \\
1.5135\end{array}$ & & $\begin{array}{l}\mathbf{0 . 2 6 9 4} \\
0.6523\end{array}$ & & $\begin{array}{l}\mathbf{0 . 1 4 4 0} \\
0.6995\end{array}$ & & $\begin{array}{l}1.5831 \\
\mathbf{0 . 8 3 9 9} \\
1.3049\end{array}$ & & $\begin{array}{l}2.6755 \\
\mathbf{0 . 2 6 1 1} \\
0.8571\end{array}$ & & $\begin{array}{l}1.4062 \\
\mathbf{0 . 2 6 9 3} \\
0.6522\end{array}$ & & $\begin{array}{l}2.8062 \\
\mathbf{0 . 1 4 4 1} \\
0.7003\end{array}$ & & $\begin{array}{l}1.6591 \\
\mathbf{0 . 1 3 8 6} \\
0.3345\end{array}$ & & $\begin{array}{l}3.2107 \\
\mathbf{0 . 1 1 8 8} \\
0.5856\end{array}$ & \\
\hline $\begin{array}{l}\text { Bank Reserves to } \\
\text { Assets ratio }\end{array}$ & -0.0030 & & -0.0048 & & -0.0068 & & -0.0091 & & -0.0027 & & -0.0062 & & -0.0068 & & -0.0091 & & -0.0078 & & -0.0112 & \\
\hline & -0.2549 & & -0.6580 & & -0.5969 & & -1.1730 & & -0.2444 & & -0.7901 & & -0.5972 & & -1.1738 & & -0.6916 & & -1.4815 & \\
\hline $\begin{array}{l}\begin{array}{l}\text { urrent A } \\
(\% \text { GDP) }\end{array}\end{array}$ & 0.0190 & & 0.0096 & & 0.0208 & & 0.0126 & & 0.0212 & & 0.0128 & & 0.0208 & & 0.0126 & & 0.0211 & & 0.0109 & \\
\hline Government & 1.4575 & & 0.9712 & & 1.5694 & & 1.3102 & & 1.5997 & & 1.2440 & & 1.5694 & & 1.3102 & & 1.5864 & & 1.1626 & \\
\hline $\begin{array}{l}\text { Expenditures } \\
\text { (\% GDP) }\end{array}$ & 0.0075 & & 0.0090 & & 0.0094 & & 0.0042 & & 0.0105 & & 0.0087 & & 0.0094 & & $\begin{array}{l}\mathbf{0 . 0 0 4 2} \\
0.5195\end{array}$ & & 0.0087 & & $\begin{array}{l}\mathbf{0 . 0 0 2 7} \\
0.3476\end{array}$ & \\
\hline $\begin{array}{l}\text { Private Capital } \\
\text { Flows (\% GDP) }\end{array}$ & -0.0053 & $* * *$ & -0.0037 & $* * *$ & -0.0052 & $* * *$ & -0.0036 & ** & -0.0051 & $* * *$ & -0.0043 & ** & -0.0052 & $* * *$ & -0.0036 & $* *$ & -0.0049 & $* * *$ & -0.0027 & $* * *$ \\
\hline & -1.9405 & & -1.7670 & & -1.8052 & & -2.0182 & & -1.7321 & & -2.2878 & & -1.8053 & & -2.0191 & & -1.7698 & & -1.6601 & \\
\hline $\begin{array}{l}\text { Overall Budget } \\
\text { (\% GDP) }\end{array}$ & -0.0222 & & -0.0192 & & -0.0112 & & -0.0109 & & 0.0008 & & -0.0038 & & -0.0112 & & -0.0109 & & -0.0146 & & -0.0139 & \\
\hline & -1.1296 & & -1.4069 & & -0.5359 & & -1.1652 & & 0.0374 & & -0.3595 & & -0.5359 & & -1.1657 & & -0.6941 & & -1.4968 & \\
\hline GDP Growth Rate & -0.0634 & * & -0.0474 & * & -0.0458 & *** & -0.0307 & ** & -0.0542 & $* *$ & -0.0293 & $* * *$ & -0.0458 & ** & -0.0307 & $* *$ & -0.0381 & $* * *$ & -0.0297 & ** \\
\hline & -2.9172 & & -3.4814 & & -2.0237 & & -2.1042 & & -2.3518 & & -1.9144 & & -2.0233 & & -2.1038 & & -1.6613 & & -2.0600 & \\
\hline $\begin{array}{l}\text { Total Trade } \\
\text { (\% GDP) }\end{array}$ & $\begin{array}{c}\mathbf{0 . 3 2 5 5} \\
0.9349\end{array}$ & & $\begin{array}{c}\mathbf{0 . 4 1 6 2} \\
2.9172\end{array}$ & * & $\begin{array}{c}\mathbf{0 . 3 1 8 5} \\
0.9370\end{array}$ & & $\begin{array}{c}\mathbf{0 . 3 3 0 3} \\
2.1914\end{array}$ & ** & $\begin{array}{c}\mathbf{0 . 2 9 2 1} \\
0.9325\end{array}$ & & $\begin{array}{l}\mathbf{0 . 3 2 2 2} \\
2.1789\end{array}$ & ** & $\begin{array}{c}\mathbf{0 . 3 1 8 5} \\
0.9368\end{array}$ & & $\begin{array}{l}\mathbf{0 . 3 3 0 1} \\
2.1902\end{array}$ & ** & $\begin{array}{c}\mathbf{0 . 3 2 2 1} \\
0.9169\end{array}$ & & $\begin{array}{c}\mathbf{0 . 3 1 6 7} \\
2.0057\end{array}$ & ** \\
\hline $\begin{array}{l}\text { Inflation Rate } \\
\text { (yearly) }\end{array}$ & $\begin{array}{l}-\mathbf{- 0 . 0 0 5 8} \\
-3.4254\end{array}$ & * & $\begin{array}{l}-\mathbf{- 0 . 0 0 4 1} \\
-4.5919\end{array}$ & * & $\begin{array}{l}-\mathbf{- 0 . 0 0 4 1} \\
-2.2859\end{array}$ & *** & $\begin{array}{l}-\mathbf{- 0 . 0 0 2 3} \\
-2.4231\end{array}$ & ** & $\begin{array}{l}-\mathbf{- 0 . 0 0 3 2} \\
-1.3181\end{array}$ & & $\begin{array}{l}-\mathbf{- 0 . 0 0 1 1} \\
-0.8701\end{array}$ & & $\begin{array}{l}-\mathbf{- 0 . 0 0 4 1} \\
-2.2855\end{array}$ & ** & $\begin{array}{l}-\mathbf{- 0 . 0 0 2 3} \\
-2.4229\end{array}$ & $* *$ & $\begin{array}{l}-\mathbf{- 0 . 0 0 3 7} \\
-2.0535\end{array}$ & ** & $\begin{array}{l}-\mathbf{- 0 . 0 0 2 2} \\
-2.3033\end{array}$ & ** \\
\hline $\begin{array}{l}\text { Trade with } \\
\text { Epicenter }\end{array}$ & $\begin{array}{c}\mathbf{- 1 3 . 0 4 3 1} \\
-1.5643 \\
\end{array}$ & & $\begin{array}{l}-6.7956 \\
-2.2431 \\
\end{array}$ & ** & $\begin{array}{c}\mathbf{- 1 3 . 1 2 8 0} \\
-1.5817 \\
\end{array}$ & & $\begin{array}{l}-6.2261 \\
-1.7988 \\
\end{array}$ & $* * *$ & $\begin{array}{c}-\mathbf{1 0 . 8 7 6 7} \\
-1.3941 \\
\end{array}$ & & $\begin{array}{l}-4.9086 \\
-1.3337 \\
\end{array}$ & & $\begin{array}{c}-\mathbf{- 1 3 . 1 2 8 7} \\
-1.5817 \\
\end{array}$ & & $\begin{array}{l}-6.2278 \\
-1.7990 \\
\end{array}$ & $* * *$ & $\begin{array}{c}-\mathbf{- 1 5 . 0 1 3 6} \\
-1.7649 \\
\end{array}$ & $* * *$ & $\begin{array}{l}-7.2368 \\
-2.1801 \\
\end{array}$ & $* *$ \\
\hline & 0.2396 & & 0.4334 & & 0.1877 & & 0.3338 & & 0.2241 & & 0.2925 & & 0.1876 & & 0.3337 & & 0.1698 & & 0.3466 & \\
\hline
\end{tabular}
IV: Intrinsic Value. $\mathrm{t}$ - statistics reported in italics.

Panel 2. Alternative Specifications

(Alternative definition of Weekly Abnormal Stock Market Returns as the Dependent Variable)

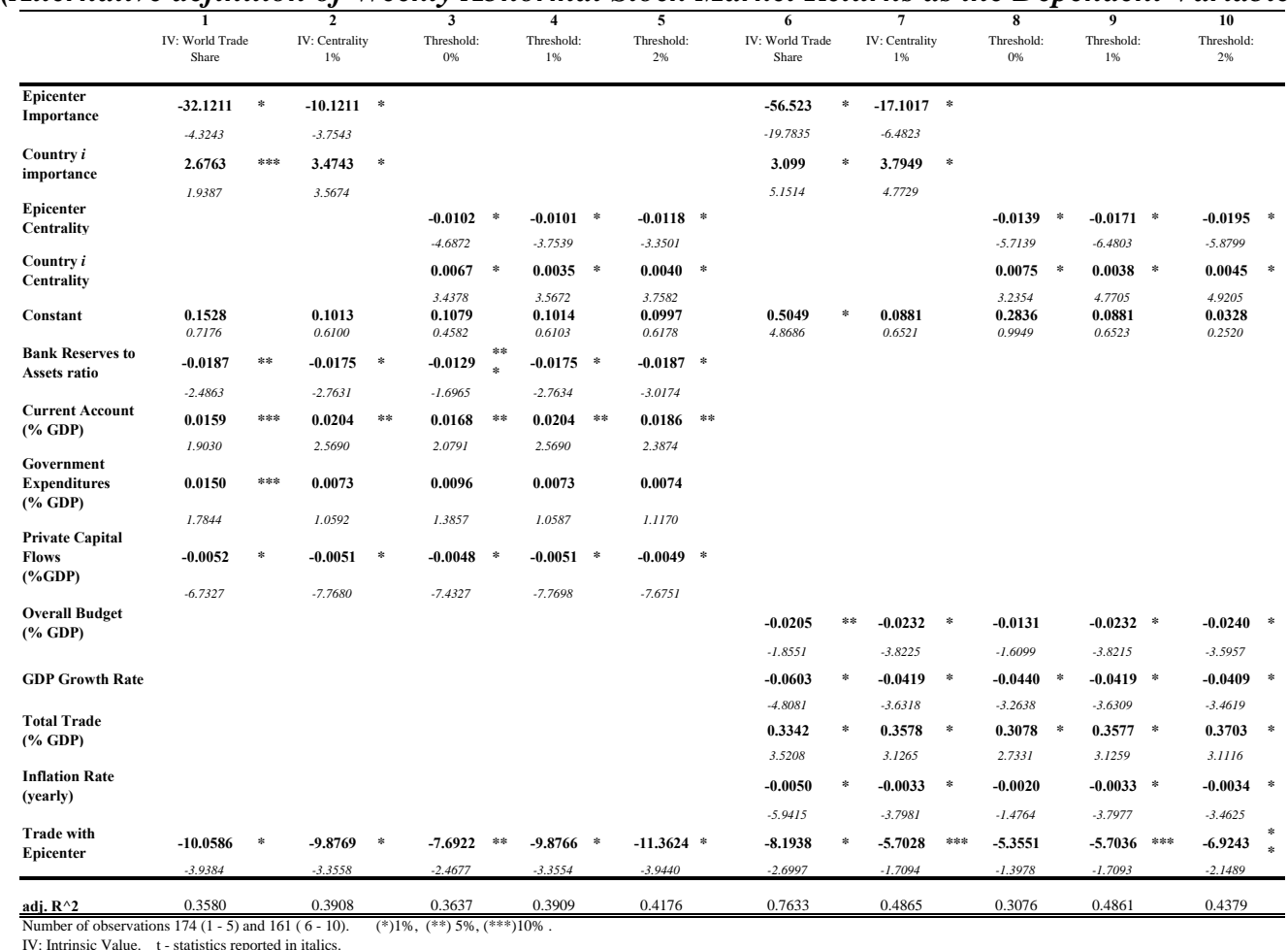


Table 12. Regression Results Using the GDP Based Node Importance and Centrality Indices as the Network Indicators

Panel 1. All Control Variables Included (Weekly Abnormal Stock Market Returns as the Dependent Variable)

\begin{tabular}{|c|c|c|c|c|c|c|c|c|c|c|c|c|c|c|c|c|c|c|c|c|}
\hline & $\begin{array}{c}\mathbf{1} \\
\text { IV: World Trade } \\
\text { Share } \\
\text { (OLS) } \\
\end{array}$ & & $\begin{array}{c}\mathbf{2} \\
\text { IV: World Trade } \\
\text { Share } \\
\text { (GLS) } \\
\end{array}$ & & $\begin{array}{c}\mathbf{3} \\
\text { IV: Centrality } \\
1 \% \\
\text { (OLS) } \\
\end{array}$ & & $\begin{array}{c}\mathbf{4} \\
\text { IV: Centrality } \\
1 \% \\
\text { (GLS) } \\
\end{array}$ & & $\begin{array}{c}\mathbf{5} \\
\text { Threshold: : \% } \\
\text { (OLS) }\end{array}$ & & $\begin{array}{c}\mathbf{6} \\
\text { Threshold: } \\
0 \% \\
\text { (GLS) } \\
\end{array}$ & & $\begin{array}{c}7 \\
\text { Threshold: } 1 \% \\
\text { (OLS) }\end{array}$ & & $\begin{array}{c}8 \\
\text { Threshold: } \\
1 \% \\
\text { (GLS) } \\
\end{array}$ & & $\begin{array}{c}9 \\
\text { Threshold: } \\
\text { 2\% } \\
\text { (OLS) }\end{array}$ & & $\begin{array}{c}\mathbf{1 0} \\
\text { Threshold: } \\
2 \% \\
\text { (GLS) } \\
\end{array}$ & \\
\hline \multirow[t]{2}{*}{ Epicenter Importance } & -65.904 & * & -44.9216 & * & -16.7575 & & -10.1070 & ** & & & & & & & & & & & & \\
\hline & -4.3736 & & -5.9292 & & -1.3398 & & -2.1607 & & & & & & & & & & & & & \\
\hline \multirow[t]{2}{*}{ Country $i$ importance } & 5.296 & ** & 3.9145 & * & 5.7134 & $* * *$ & 3.0183 & $* *$ & & & & & & & & & & & & \\
\hline & 2.2093 & & 3.1751 & & 1.6835 & & 2.0844 & & & & & & & & & & & & & \\
\hline \multirow[t]{2}{*}{ Epicenter Centrality } & & & & & & & & & -0.0245 & * & -0.0112 & * & -0.017 & & -0.0101 & $* *$ & -0.008 & & -0.0095 & $* * *$ \\
\hline & & & & & & & & & -3.3998 & & -3.1866 & & -1.3431 & & -2.1666 & & -0.5211 & & -1.7888 & \\
\hline Country $i$ Centrality & & & & & & & & & 0.0147 & $* *$ & 0.0092 & $* *$ & 0.0057 & $* * *$ & 0.0030 & $* *$ & 0.0092 & $* *$ & 0.0043 & $* *$ \\
\hline Constant & $\begin{array}{l}\mathbf{0 . 0 2 8 3} \\
0.0533\end{array}$ & & $\begin{array}{l}-\mathbf{0 . 4 8 6 4} \\
-2.1768\end{array}$ & $* *$ & $\begin{array}{l}-\mathbf{0 . 4 6 0 5} \\
-0.9481\end{array}$ & & $\begin{array}{l}-\mathbf{0 . 4 2 0 1} \\
-1.7206\end{array}$ & $* * *$ & $\begin{array}{c}2.3309 \\
-\mathbf{0 . 0 3 4 3 0} \\
-0.0422\end{array}$ & & $\begin{array}{c}2.5412 \\
-\mathbf{- 0 . 6 2 9 0 0} \\
-1.6099\end{array}$ & & $\begin{array}{l}1.6820 \\
\mathbf{- 0 . 4 5 8} \\
-0.9440\end{array}$ & & $\begin{array}{c}2.0901 \\
-\mathbf{- 0 . 4 4 1 8 8} \\
-1.7175\end{array}$ & $* * *$ & $\begin{array}{l}2.0832 \\
-\mathbf{- 0 . 6 0 8} \\
-1.2357\end{array}$ & & $\begin{array}{c}2.2245 \\
-\mathbf{- 0 . 4 4 4 0} \\
-2.0033\end{array}$ & $* *$ \\
\hline \multirow{2}{*}{$\begin{array}{l}\text { Bank Reserves to } \\
\text { Assets ratio }\end{array}$} & -0.0039 & & -0.0052 & & -0.0063 & & -0.0136 & & 0.0003 & & -0.007 & & -0.0064 & & -0.014 & & -0.0057 & & -0.0128 & \\
\hline & -0.2425 & & -0.4603 & & -0.3918 & & -1.3303 & & 0.0214 & & -0.6574 & & -0.3921 & & -1.3256 & & -0.3464 & & -1.2753 & \\
\hline \multirow[t]{2}{*}{$\begin{array}{l}\text { Current Account } \\
(\% \text { GDP) }\end{array}$} & 0.0246 & & 0.0217 & $* *$ & 0.0299 & & 0.0270 & * & 0.0251 & & 0.0267 & $* *$ & 0.0299 & & 0.0270 & $*$ & 0.0308 & & 0.0283 & * \\
\hline & 1.3525 & & 2.0577 & & 1.5673 & & 2.8340 & & 1.3558 & & 2.5329 & & 1.5687 & & 2.8367 & & 1.6315 & & 3.0495 & \\
\hline $\begin{array}{l}\text { Government } \\
\text { Expenditures } \\
\text { (\% GDP) }\end{array}$ & 0.0316 & $* * *$ & 0.0309 & $*$ & $\begin{array}{l}\mathbf{0 . 0 3 0 9} \\
1.8397\end{array}$ & $* * *$ & 0.0253 & $* *$ & $\begin{array}{l}\mathbf{0 . 0 3 3 3} \\
1.9771\end{array}$ & *** & $\begin{array}{l}\mathbf{0 . 0 3 1 1} \\
3.0000\end{array}$ & * & $\begin{array}{l}\mathbf{0 . 0 3 0 9} \\
1.8359\end{array}$ & *** & $\begin{array}{l}\mathbf{0 . 0 2 5 3} \\
2.4751\end{array}$ & $* *$ & $\begin{array}{l}\mathbf{0 . 0 3 0 7} \\
1.8483\end{array}$ & $* * *$ & $\begin{array}{l}\mathbf{0 . 0 2 5 4} \\
2.5074\end{array}$ & $* *$ \\
\hline \multirow[t]{2}{*}{$\begin{array}{l}\text { Private Capital Flows } \\
\text { (\% GDP) }\end{array}$} & -0.0043 & & 0.0002 & & -0.0041 & & -0.0007 & & -0.0045 & & -0.0015 & & -0.0041 & & -0.0007 & & -0.0039 & & -0.0003 & \\
\hline & -1.3154 & & 0.1208 & & -1.2919 & & -0.4573 & & -1.3529 & & -0.8137 & & -1.2973 & & -0.4622 & & -1.2785 & & -0.2317 & \\
\hline \multirow{2}{*}{$\begin{array}{l}\text { Overall Budget } \\
\text { (\% GDP) }\end{array}$} & -0.0288 & & -0.0566 & $*$ & -0.0204 & & -0.0453 & * & 0.0033 & & -0.027 & $* * *$ & -0.020 & & -0.045 & * & -0.346 & & -0.0483 & * \\
\hline & -1.0004 & & -3.6587 & & -0.6668 & & -3.4421 & & 0.1143 & & -1.6818 & & -0.6700 & & -3.4512 & & -0.8741 & & -3.7350 & \\
\hline \multirow[t]{2}{*}{ GDP Growth Rate } & -0.0998 & $*$ & -0.0662 & $*$ & -0.0592 & & -0.0430 & ** & -0.0782 & ** & -0.042 & *** & -0.059 & & -0.043 & $* *$ & -0.052 & & -0.0360 & $* *$ \\
\hline & -2.6836 & & -3.0620 & & -1.5760 & & -2.5248 & & -2.1716 & & -2.1177 & & -1.5760 & & -2.5220 & & -1.3825 & & -2.2622 & \\
\hline \multirow{2}{*}{$\begin{array}{l}\text { Total Trade } \\
\text { (\% GDP) }\end{array}$} & 0.4981 & & 0.3884 & $* *$ & 0.4160 & & 0.0716 & & 0.3730 & & 0.1294 & & 0.4147 & & 0.0704 & & 0.4275 & & 0.0867 & \\
\hline & 1.3534 & & 2.0759 & & 1.0879 & & 0.3444 & & 1.1245 & & 0.6374 & & 1.0853 & & 0.3391 & & 1.0860 & & 0.4106 & \\
\hline \multirow{2}{*}{$\begin{array}{l}\text { Inflation Rate } \\
\text { (yearly) }\end{array}$} & -0.0034 & & 0.0028 & & -0.0059 & & 0.0014 & & -0.0026 & & 0.0031 & & -0.0060 & & 0.0013 & & -0.006 & & 0.0009 & \\
\hline & -0.3660 & & 0.4750 & & -0.5403 & & 0.2348 & & -0.2391 & & 0.4681 & & -0.5430 & & 0.2292 & & -0.5592 & & 0.1638 & \\
\hline Trade with Epicenter & $\begin{array}{l}-\mathbf{- 1 3 . 6 7 1 3} \\
-1.5634\end{array}$ & & $\begin{array}{l}-5.2715 \\
-1.6030\end{array}$ & & $\begin{array}{l}-\mathbf{- 1 7 . 7 4 9 3} \\
-1.8647\end{array}$ & $* * *$ & $\begin{array}{l}-9.8782 \\
-2.8918\end{array}$ & * & $\begin{array}{l}-12.1433 \\
-1.3817\end{array}$ & & $\begin{array}{l}-5.2953 \\
-1.2087\end{array}$ & & $\begin{array}{l}-17.7247 \\
-1.8631\end{array}$ & $* * *$ & $\begin{array}{l}-9.8623 \\
-2.8893\end{array}$ & * & $\begin{array}{l}-\mathbf{1 9 . 5 4 2} \\
-2.0565\end{array}$ & $* *$ & $\begin{array}{l}-10.3724 \\
-3.0550\end{array}$ & $*$ \\
\hline $\operatorname{adj} . R^{\wedge} 2$ & 0.3030 & & 0.4725 & & 0.2209 & & 0.3941 & & 0.2861 & & 0.3362 & & 0.2209 & & 0.3945 & & 0.2173 & & 0.3742 & \\
\hline
\end{tabular}

Panel 2. Alternative Specifications

(Weekly Abnormal Stock Market Returns as the Dependent Variable)

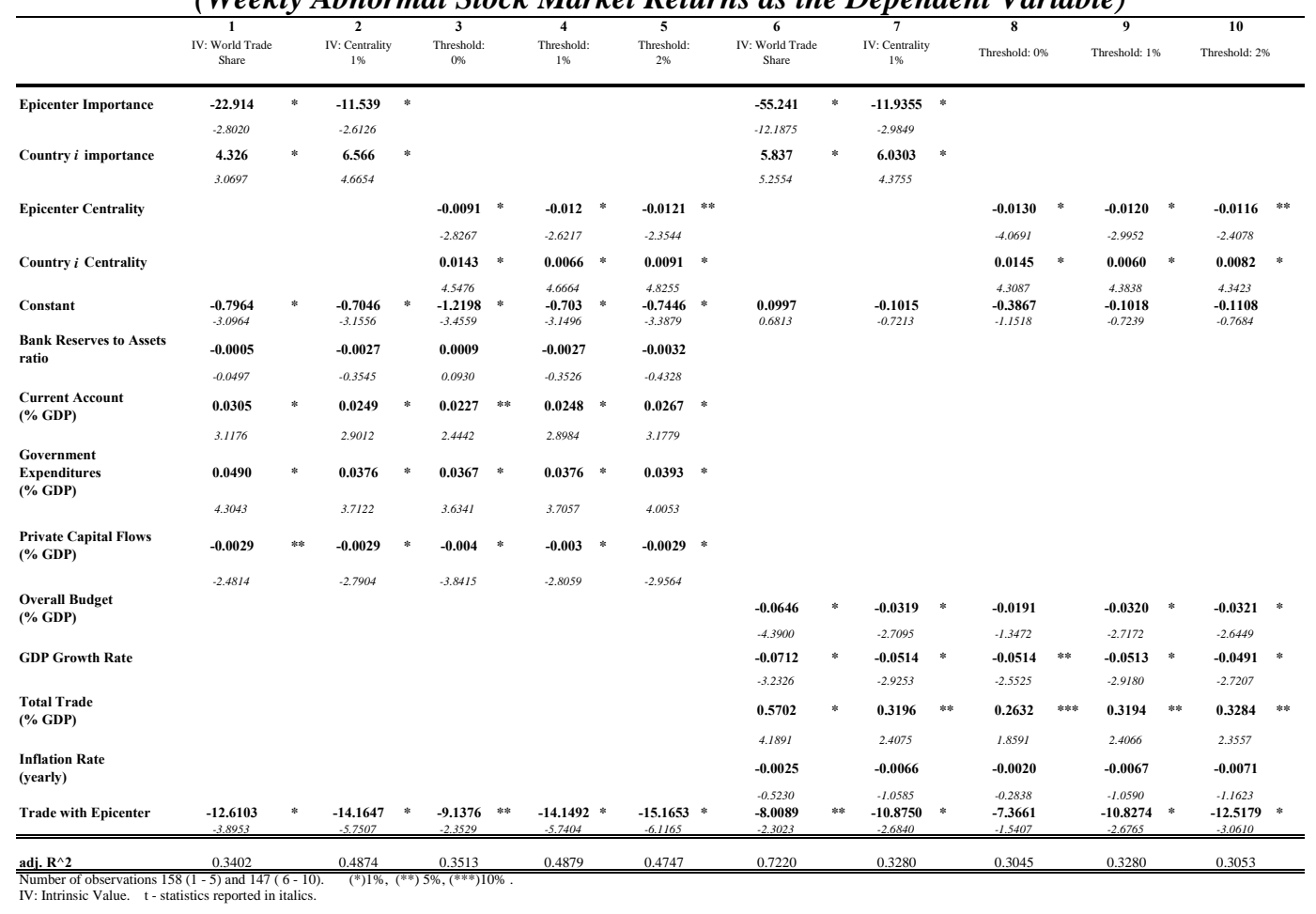


Table 13. Regression Results Using the GDP Based Node Importance and Centrality Indices as the Network Indicators

Panel 1. All Control Variables Included (Alternative Definition of Weekly Abnormal Stock Market Returns as the Dependent Variable)

\begin{tabular}{|c|c|c|c|c|c|c|c|c|c|c|c|c|c|c|c|c|c|c|c|c|}
\hline & $\begin{array}{c}1 \\
\text { IV: World Trade } \\
\text { Share } \\
\text { (OLS) } \\
\end{array}$ & & $\begin{array}{c}\mathbf{2} \\
\text { IV: World Trade } \\
\text { Share } \\
\text { (GLS) } \\
\end{array}$ & & $\begin{array}{c}\mathbf{3} \\
\text { IV: Centrality } \\
1 \% \\
\text { (OLS) } \\
\end{array}$ & & $\begin{array}{c}\mathbf{4} \\
\text { IV: Centrality } \\
1 \% \\
\text { (GLS) } \\
\end{array}$ & & $\begin{array}{c}\mathbf{5} \\
\text { Threshold: } \\
0 \% \\
\text { (OLS) } \\
\end{array}$ & & $\begin{array}{c}\mathbf{6} \\
\text { Threshold: } \\
0 \% \\
\text { (GLS) } \\
\end{array}$ & & $\begin{array}{c}7 \\
\text { Threshold: } \\
1 \% \\
\text { (OLS) } \\
\end{array}$ & & $\begin{array}{c}\mathbf{8} \\
\text { Threshold: } \\
1 \% \\
\text { (GLS) } \\
\end{array}$ & & $\begin{array}{c}\mathbf{9} \\
\text { Threshold: } \\
2 \% \\
\text { (OLS) } \\
\end{array}$ & & $\begin{array}{c}\mathbf{1 0} \\
\text { Threshold: } \\
2 \% \\
\text { (GLS) } \\
\end{array}$ & \\
\hline $\begin{array}{l}\text { Epicenter } \\
\text { Importance }\end{array}$ & -59.3082 & * & -47.9977 & * & -20.7733 & ** & -20.1186 & * & & & & & & & & & & & & \\
\hline & -4.8570 & & -8.5598 & & -2.1165 & & -4.3026 & & & & & & & & & & & & & \\
\hline $\begin{array}{l}\text { Country } i \\
\text { importance }\end{array}$ & $\begin{array}{l}3.5054 \\
1.5799\end{array}$ & & $\begin{array}{l}2.5225 \\
24861\end{array}$ & ** & $\begin{array}{l}4.4389 \\
1.5780\end{array}$ & & 4.1077 & * & & & & & & & & & & & & \\
\hline $\begin{array}{l}\text { Epicenter } \\
\text { Centrality }\end{array}$ & 1.0753 & & 2.40001 & & $1.5 \% 00$ & & .1 .002 & & $\begin{array}{l}-\mathbf{- 0 . 0 2 3 4} \\
-4.2584\end{array}$ & * & $\begin{array}{l}-\mathbf{- 0 . 0 1 4 5} \\
-4.8398\end{array}$ & * & $\begin{array}{l}-\mathbf{- 0 . 0 2 0 8} \\
-2.1192\end{array}$ & *** & $\begin{array}{l}-\mathbf{- 0 . 0 2 0 1} \\
-4.3051\end{array}$ & * & -0.0144 & & $\begin{array}{l}-\mathbf{- 0 . 0 2 1 5} \\
-4.0131\end{array}$ & * \\
\hline $\begin{array}{l}\text { Country } i \\
\text { Centrality }\end{array}$ & & & & & & & & & 0.0086 & & 0.0069 & * & 0.0044 & & 0.0041 & * & 0.0072 & $* * *$ & 0.0058 & * \\
\hline Constant & $\begin{array}{l}\mathbf{0 . 5 5 1 4} \\
1.2670\end{array}$ & & $\begin{array}{l}\mathbf{0 . 2 5 9 6} \\
1.5126\end{array}$ & & $\begin{array}{c}\mathbf{0 . 0 8 5 8} \\
0.2034\end{array}$ & & $\begin{array}{l}\mathbf{0 . 1 0 6 0} \\
0.5274\end{array}$ & & $\begin{array}{l}1.6511 \\
\mathbf{0 . 8 5 2 8} \\
1.3201\end{array}$ & & $\begin{array}{l}2.7178 \\
\mathbf{0 . 2 6 5 7} \\
0.8614\end{array}$ & & $\begin{array}{c}1.5747 \\
\mathbf{0 . 0 8 8 5} \\
0.2104\end{array}$ & & $\begin{array}{l}3.1527 \\
\mathbf{0 . 1 0 7 3} \\
0.5346\end{array}$ & & $\begin{array}{c}1.8573 \\
-\mathbf{- 0 . 0 4 9 2} \\
-0.1149\end{array}$ & & $\begin{array}{l}3.3213 \\
\mathbf{0 . 0 1 9 7} \\
0.0943\end{array}$ & \\
\hline $\begin{array}{l}\text { Bank Reserves to } \\
\text { Assets ratio }\end{array}$ & -0.0030 & & -0.0048 & & -0.0079 & & -0.0117 & & -0.0024 & & -0.0059 & & -0.0080 & & -0.0117 & & -0.0081 & & -0.0122 & *** \\
\hline & -0.2550 & & -0.6577 & & -0.6976 & & -1.5652 & & -0.2200 & & -0.7442 & & -0.7004 & & -1.5664 & & -0.7091 & & -1.6807 & \\
\hline $\begin{array}{l}\text { Current Account } \\
(\% \text { GDP })\end{array}$ & 0.0190 & & 0.0096 & & 0.0214 & & 0.0104 & & 0.0209 & & 0.0123 & & 0.0215 & & 0.0105 & & 0.0215 & & 0.0100 & \\
\hline Government & 1.4575 & & 0.9714 & & 1.6057 & & 1.1260 & & 1.5788 & & 1.2062 & & 1.6073 & & 1.1290 & & 1.6073 & & 1.1345 & \\
\hline $\begin{array}{l}\text { Expenditures } \\
\text { (\% GDP) }\end{array}$ & 0.0075 & & 0.0090 & & 0.0087 & & 0.0026 & & 0.0107 & & 0.0091 & & 0.0087 & & 0.0026 & & 0.0080 & & 0.0032 & \\
\hline $\begin{array}{l}\text { Private Capital } \\
\text { Flows (\% GDP) }\end{array}$ & $\begin{array}{c}0.5541 \\
-\mathbf{- 0 . 0 0 5 3}\end{array}$ & *** & $\begin{array}{c}1.0920 \\
-\mathbf{- 0 . 0 0 3 7}\end{array}$ & $* * *$ & $\begin{array}{c}0.6218 \\
-\mathbf{- 0 . 0 0 4 8}\end{array}$ & $* * *$ & $\begin{array}{c}0.3338 \\
-\mathbf{- 0 . 0 0 2 5}\end{array}$ & & $\begin{array}{c}0.7715 \\
\mathbf{- 0 . 0 0 5 0}\end{array}$ & $* * *$ & $\begin{array}{c}1.0425 \\
-\mathbf{- 0 . 0 0 4 3}\end{array}$ & ** & $\begin{array}{c}0.6189 \\
-\mathbf{0 . 0 0 4 8}\end{array}$ & *** & $\begin{array}{c}0.3315 \\
\mathbf{- 0 . 0 0 2 5}\end{array}$ & & $\begin{array}{c}0.5744 \\
\mathbf{- 0 . 0 0 4 7}\end{array}$ & $* * *$ & $\begin{array}{c}0.4138 \\
-\mathbf{- 0 . 0 0 1 8}\end{array}$ & \\
\hline Overall Budget & -1.9402 & & -1.7664 & & -1.7376 & & -1.5564 & & -1.7153 & & -2.2659 & & -1.7421 & & -1.5602 & & -1.7462 & & -1.1305 & \\
\hline $\begin{array}{l}\text { Overall Budget } \\
\text { \% GDP) }\end{array}$ & $\begin{array}{l}-\mathbf{- 0 . 0 2 2 2} \\
-1.1292\end{array}$ & & $\begin{array}{l}-\mathbf{- 0 . 0 1 9 2} \\
-1.4065\end{array}$ & & $\begin{array}{l}-\mathbf{- 0 . 0 1 5 5} \\
-0.7275\end{array}$ & & $\begin{array}{l}-\mathbf{- 0 . 0 1 3 9} \\
-1.5180\end{array}$ & & $\begin{array}{c}\mathbf{0 . 0 0 1 5} \\
0.0710\end{array}$ & & $\begin{array}{l}-\mathbf{- 0 . 0 0 3 3} \\
-0.3106\end{array}$ & & $\begin{array}{l}-\mathbf{- 0 . 0 1 5 6} \\
-0.7316\end{array}$ & & $\begin{array}{l}-\mathbf{- 0 . 0 1 4 0} \\
-1.5228\end{array}$ & & $\begin{array}{l}-\mathbf{- 0 . 0 2 1 7} \\
-1.0003\end{array}$ & & $\begin{array}{l}-\mathbf{- 0 . 0 1 6 1} \\
-1.7065\end{array}$ & $* * *$ \\
\hline GDP Growth Rate & $\begin{array}{c}-\mathbf{0 . 0 6 3 4} \\
-2.9174\end{array}$ & * & $\begin{array}{l}-\mathbf{- 0 . 0 4 7 4} \\
-3.4815\end{array}$ & * & $\begin{array}{l}-\mathbf{- 0 . 0 3 5 2} \\
-1.5230\end{array}$ & & $\begin{array}{c}-\mathbf{- 0 . 0 2 8 3} \\
-1.9736\end{array}$ & $* * *$ & $\begin{array}{c}-\mathbf{0 . 0 5 4 9} \\
-2.3918\end{array}$ & $* *$ & $\begin{array}{l}-\mathbf{- 0 . 0 3 0 0} \\
-1.9632\end{array}$ & $* * *$ & $\begin{array}{l}-\mathbf{- 0 . 0 3 5 2} \\
-1.5245\end{array}$ & & $\begin{array}{l}-\mathbf{- 0 . 0 2 8 3} \\
-1.9767\end{array}$ & $* * *$ & $\begin{array}{c}-\mathbf{- 0 . 0 2 9 0} \\
-1.2469\end{array}$ & & $\begin{array}{l}-\mathbf{- 0 . 0 2 6 5} \\
-1.8781\end{array}$ & $* * *$ \\
\hline $\begin{array}{l}\text { Total Trade } \\
\text { (\% GDP) }\end{array}$ & $\begin{array}{c}\mathbf{0 . 3 2 5 5} \\
0.9350\end{array}$ & & $\begin{array}{c}\mathbf{0 . 4 1 6 3} \\
2.9179\end{array}$ & * & $\begin{array}{c}\mathbf{0 . 3 1 6 3} \\
0.8971\end{array}$ & & $\begin{array}{l}\mathbf{0 . 2 9 6 9} \\
1.9122\end{array}$ & $* * *$ & $\begin{array}{c}\mathbf{0 . 2 8 7 1} \\
0.9164\end{array}$ & & $\begin{array}{r}\mathbf{0 . 3 2 3 1} \\
2.1694\end{array}$ & $* *$ & $\begin{array}{l}\mathbf{0 . 3 1 5 2} \\
0.8947\end{array}$ & & $\begin{array}{l}\mathbf{0 . 2 9 6 0} \\
1.9068\end{array}$ & $* * *$ & $\begin{array}{c}\mathbf{0 . 3 2 7 6} \\
0.9010\end{array}$ & & $\begin{array}{c}\mathbf{0 . 2 9 5 3} \\
1.7432\end{array}$ & $* * *$ \\
\hline $\begin{array}{l}\text { Inflation Rate } \\
\text { (yearly) }\end{array}$ & $\begin{array}{l}-\mathbf{0 . 0 0 5 8} \\
-3.4255\end{array}$ & * & $\begin{array}{c}-\mathbf{- 0 . 0 0 4 1} \\
-4.5918\end{array}$ & * & $\begin{array}{l}-\mathbf{- 0 . 0 0 3 6} \\
-1.9334\end{array}$ & $* * *$ & $\begin{array}{l}-\mathbf{0 . 0 0 2 1} \\
-2.1895\end{array}$ & $* *$ & $\begin{array}{c}-\mathbf{- 0 . 0 0 3 1} \\
-1.2836\end{array}$ & & $\begin{array}{l}-\mathbf{- 0 . 0 0 1 0} \\
-0.8363\end{array}$ & & $\begin{array}{l}-\mathbf{0 . 0 0 3 6} \\
-1.9393\end{array}$ & $* * *$ & $\begin{array}{l}-\mathbf{0 . 0 0 2 1} \\
-2.1957\end{array}$ & ** & $\begin{array}{l}-\mathbf{0 . 0 0 3 2} \\
-1.7516\end{array}$ & $* * *$ & $\begin{array}{l}-\mathbf{0 . 0 0 1 9} \\
-1.9985\end{array}$ & $* *$ \\
\hline $\begin{array}{l}\text { Trade with } \\
\text { Epicenter }\end{array}$ & $\begin{array}{c}\mathbf{- 1 3 . 0 4 1 2} \\
-1.5641 \\
\end{array}$ & & $\begin{array}{l}-6.7930 \\
-2.2423 \\
\end{array}$ & ** & $\begin{array}{c}-\mathbf{- 1 5 . 6 1 5 1} \\
-1.8245 \\
\end{array}$ & $* * *$ & $\begin{array}{c}-\mathbf{- 7 . 6 2 2 6} \\
-2.2932 \\
\end{array}$ & $* *$ & $\begin{array}{c}\mathbf{- 1 0 . 7 3 5 9} \\
-1.3750 \\
\end{array}$ & & $\begin{array}{r}-\mathbf{4 . 8 1 2 3} \\
-1.3050 \\
\end{array}$ & & $\begin{array}{c}\mathbf{- 1 5 . 5 9 3 9} \\
-1.8229 \\
\end{array}$ & $* * *$ & $\begin{array}{r}-\mathbf{- 7 . 6 1 4 8} \\
-2.2918 \\
\end{array}$ & $* *$ & $\begin{array}{c}-17.3997 \\
-2.0092 \\
\end{array}$ & ** & $\begin{array}{l}\mathbf{- 8 . 5 9 7 5} \\
-2.5827 \\
\end{array}$ & ** \\
\hline adj. $R^{\wedge} 2$ & 0.2396 & & 0.4333 & & 0.1623 & & 0.3518 & & 0.2266 & & 0.2941 & & 0.1622 & & 0.3519 & & 0.1510 & & 0.3496 & \\
\hline
\end{tabular}

Panel 2. Alternative Specifications

(Alternative Definition of Weekly Abnormal Stock Market Returns as the Dependent Variable)

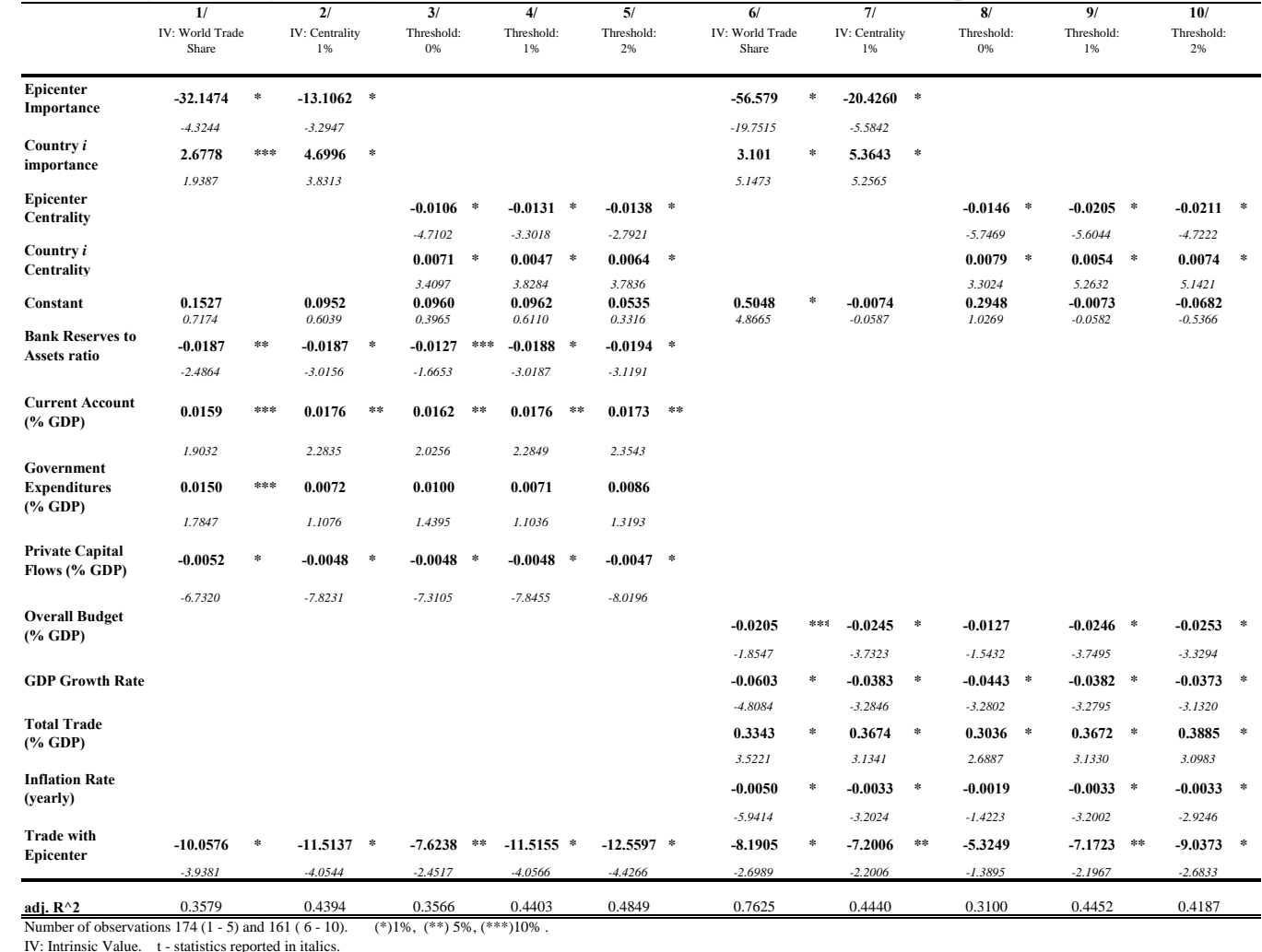


Table 14. Effects of One Standard Deviation Increase of the Network Indicator on the Weekly Abnormal Stock Market Return

\begin{tabular}{|c|c|c|c|c|c|c|}
\hline & \multicolumn{2}{|c|}{ Effects in Terms of Standard Deviations } & \multicolumn{2}{|c|}{ Effects in terms of Percentage Points } & \multicolumn{2}{|c|}{$\begin{array}{c}\text { Accumulated Effects Over a Period of } 10 \text { Weeks } \\
\text { in Terms of Percentage Points }\end{array}$} \\
\hline & Specification (A) GLS & Specification (B) GLS & $\begin{array}{r}T a \\
\text { Specification (A) GLS }\end{array}$ & $\begin{array}{l}10 \\
\text { Specification (B) GLS }\end{array}$ & Specification (A) GLS & Specification (B) GLS \\
\hline $\begin{array}{l}\text { Epicenter Importance (IV: world trade share) } \\
\end{array}$ & $\begin{array}{ll}-0.096 \\
\end{array}$ & -0.230 & $\begin{array}{cc}-0.122 \\
\end{array}$ & $\begin{array}{ll}-0.294 \\
\end{array}$ & -1.220 & -2.942 \\
\hline \multirow[t]{2}{*}{ Country i importance (IV: world trade share) } & 0.093 & 0.126 & 0.119 & 0.160 & 1.189 & 1.604 \\
\hline & \multicolumn{6}{|c|}{ Table 11 Panel 1} \\
\hline $\begin{array}{l}\text { Epicenter Importance (IV: world trade share) } \\
\end{array}$ & -0.275 & -0.223 & 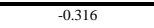 & -0.256 & -3.158 & -2.556 \\
\hline \multirow[t]{2}{*}{ Country i importance (IV: world trade share) } & 0.084 & 0.060 & 0.096 & 0.069 & 0.963 & 0.693 \\
\hline & \multicolumn{6}{|c|}{ Table 11 Panel 2} \\
\hline 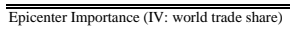 & -0.134 & -0.236 & $\begin{array}{c}\text { Specirication (A) GLS } \\
-0.171\end{array}$ & $\begin{array}{c}\text { Specincation (B) GLS } \\
0.301\end{array}$ & $\begin{array}{c}\text { Specincation (A) GLS } \\
-1.712\end{array}$ & -3.013 \\
\hline \multirow[t]{2}{*}{ Country i importance (IV: world trade share) } & 0.058 & 0.067 & 0.074 & 0.085 & 0.736 & 0.852 \\
\hline & \multicolumn{6}{|c|}{ Table 12 Panel 1} \\
\hline $\begin{array}{l}\text { Epicenter Importance (IV: world trade share) } \\
\end{array}$ & -0.275 & 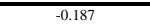 & -0.351 & $0-0.239$ & 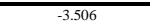 & 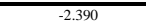 \\
\hline \multirow[t]{2}{*}{ Country i importance (IV: world trade share) } & 0.114 & 0.084 & 0.146 & 0.108 & 1.456 & 1.076 \\
\hline & \multicolumn{6}{|c|}{$\begin{array}{ll}\text { Table } 12 \text { Panel } 2 \\
\end{array}$} \\
\hline $\begin{array}{l}\text { Epicenter Importance (IV: world trade share) } \\
\end{array}$ & $\begin{array}{ll}-0.095 \\
\end{array}$ & $\begin{array}{ll}-0.230 \\
\end{array}$ & $\begin{array}{cc}-0.122 \\
\end{array}$ & $\begin{array}{ll}-0.294 \\
\end{array}$ & $\begin{array}{ll} & -1.219 \\
\end{array}$ & $\begin{array}{ll}-2.939 \\
\end{array}$ \\
\hline \multirow[t]{2}{*}{ Country i importance (IV: world trade share) } & 0.093 & 0.126 & 0.119 & 0.161 & 1.190 & 1.605 \\
\hline & \multicolumn{6}{|c|}{$\begin{array}{l} \\
\end{array}$ Table 13 Panel 1} \\
\hline $\begin{array}{l}\text { Epicenter Importance (IV: world trade share) } \\
\end{array}$ & 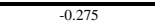 & 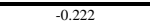 & 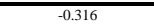 & -0.255 & -3.155 & -2.553 \\
\hline \multirow[t]{3}{*}{ Country i importance (IV: world trade share) } & 0.084 & 0.060 & 0.096 & 0.069 & 0.964 & 0.694 \\
\hline & \multicolumn{6}{|c|}{ Table 13 Panel 2} \\
\hline & Specification (A) GLS & Specification (B) GLS & Specification (A) GLS & Specification (B) GLS & Specification (A) GLS & Specification (B) GLS \\
\hline Epicenter Importance (IV: world trade share) & $\begin{array}{ll}-0.149 \\
\end{array}$ & $\begin{array}{ll}-0.262 \\
\end{array}$ & $\begin{array}{cc}-0.171 \\
\end{array}$ & $\begin{array}{c}-0.301 \\
\end{array}$ & $\begin{array}{ll}-1.710 \\
\end{array}$ & $\begin{array}{ll}-3.010 \\
\end{array}$ \\
\hline Country i importance (IV: world trade share) & 0.064 & 0.074 & 0.074 & 0.085 & 0.736 & 0.853 \\
\hline
\end{tabular}

Table 15. Regression Results Using Node Importance and Centrality Indices as the Network Indicators (Excluding the Argentinean Crisis Window) (Weekly Abnormal Stock Market Returns as the Dependent Variable)

\begin{tabular}{|c|c|c|c|c|c|c|c|c|c|c|c|c|c|c|c|c|c|c|c|c|}
\hline & $\begin{array}{c}\mathbf{1} \\
\text { IV: World Trade } \\
\text { Share } \\
\text { (OLS) } \\
\end{array}$ & & $\begin{array}{c}\mathbf{2} \\
\text { IV: World Trade } \\
\text { Share } \\
\text { (GLS) } \\
\end{array}$ & & $\begin{array}{c}3 \\
\text { IV: Centrality } \\
1 \% \\
\text { (OLS) } \\
\end{array}$ & & $\begin{array}{c}4 \\
\text { IV: Centrality } \\
\text { 1\% } \\
\text { (GLS) } \\
\end{array}$ & & $\begin{array}{c}\mathbf{5} \\
\text { Threshold: } \\
0 \% \\
\text { (OLS) } \\
\end{array}$ & & $\begin{array}{c}\mathbf{6} \\
\text { Threshold: } \\
0 \% \\
\text { (GLS) } \\
\end{array}$ & & $\begin{array}{c}7 \\
\text { Threshold: } \\
1 \% \\
\text { (oLS) } \\
\end{array}$ & & $\begin{array}{c}\mathbf{8} \\
\text { Threshold: } \\
1 \% \\
\text { (GLS) } \\
\end{array}$ & & $\begin{array}{c}\mathbf{9} \\
\text { Threshold: } \\
\text { 2\% } \\
\text { (OLS) } \\
\end{array}$ & & $\begin{array}{c}10 \\
\text { Threshold: } \\
2 \% \\
\text { (GLS) } \\
\end{array}$ & \\
\hline $\begin{array}{l}\text { Epicenter } \\
\text { Importance }\end{array}$ & -80.320 & * & -52.898 & * & -26.0617 & $* *$ & -15.7774 & * & & & & & & & & & & & & \\
\hline & -4.6669 & & -6.0751 & & -2.6211 & & -4.0633 & & & & & & & & & & & & & \\
\hline $\begin{array}{l}\text { Country } i \\
\text { importance }\end{array}$ & $\begin{array}{l}\mathbf{5 . 3 9 2} \\
1.9355\end{array}$ & $* * *$ & $\begin{array}{l}3.475 \\
2.4906\end{array}$ & ** & $\begin{array}{l}2.8808 \\
0.9496\end{array}$ & & $\begin{array}{l}\mathbf{1 . 3 9 9 5} \\
1.0369\end{array}$ & & & & & & & & & & & & & \\
\hline $\begin{array}{l}\text { Epicenter } \\
\text { Centrality }\end{array}$ & & & & & & & & & $\begin{array}{l}-\mathbf{- 0 . 0 2 4 4} \\
-3.3327\end{array}$ & * & $\begin{array}{l}-\mathbf{- 0 . 0 1 1 3} \\
-3.2850\end{array}$ & * & $\begin{array}{l}-\mathbf{- 0 . 0 2 6 1} \\
-2.6200\end{array}$ & ** & $\begin{array}{l}-\mathbf{- 0 . 0 1 5 8} \\
-4.0607\end{array}$ & * & $\begin{array}{l}-\mathbf{- 0 . 0 2 2 5} \\
-1.7212\end{array}$ & $* * *$ & $\begin{array}{l}-\mathbf{- 0 . 0 1 8 6} \\
-4.1835\end{array}$ & * \\
\hline $\begin{array}{l}\text { Country } i \\
\text { Centrality }\end{array}$ & & & & & & & & & 0.0124 & **** & 0.0067 & $* * *$ & 0.0029 & & 0.0014 & & 0.0045 & & 0.0022 & *** \\
\hline Constant & $\begin{array}{c}\mathbf{0 . 3 4 7 9} \\
0.5838\end{array}$ & & $\begin{array}{l}-\mathbf{- 0 . 4 0 0 2} \\
-1.5609\end{array}$ & & $\begin{array}{l}-\mathbf{- 0 . 0 1 8 1} \\
-0.0334\end{array}$ & & $\begin{array}{l}-\mathbf{- 0 . 3 8 5 4} \\
-1.5031\end{array}$ & & $\begin{array}{l}1.7042 \\
\mathbf{0 . 1 8 2 0} \\
0.1997\end{array}$ & & $\begin{array}{c}1.8047 \\
\mathbf{- 0 . 5 0 3 8} \\
-1.2191\end{array}$ & & $\begin{array}{c}0.9473 \\
\mathbf{- 0 . 0 1 8 2} \\
-0.0335\end{array}$ & & $\begin{array}{c}1.0351 \\
\mathbf{- 0 . 3 8 5 2} \\
-1.5024\end{array}$ & & $\begin{array}{c}1.4405 \\
-\mathbf{- 0 . 2 8 0 2} \\
-0.5223\end{array}$ & & $\begin{array}{c}1.7345 \\
\mathbf{- 0 . 4 2 1 6} \\
-1.7121\end{array}$ & **** \\
\hline $\begin{array}{l}\text { Bank Reserves to } \\
\text { Assets ratio }\end{array}$ & $\begin{array}{l}\mathbf{0 . 0 0 2 1} \\
0.1076\end{array}$ & & 0.0077 & & $\begin{array}{l}-\mathbf{0 . 0 0 3 3} \\
-0.1685\end{array}$ & & $\begin{array}{l}-\mathbf{0 . 0 0 0 6} \\
-0.0464\end{array}$ & & $\begin{array}{l}\mathbf{0 . 0 0 1 2} \\
0.0643\end{array}$ & & -0.0006 & & -0.0033 & & $\begin{array}{l}-\mathbf{0 . 0 0 0 6} \\
-0.0470\end{array}$ & & -0.0036 & & 0.0001 & \\
\hline $\begin{array}{l}\text { Current Account } \\
(\% \text { GDP) }\end{array}$ & 0.0287 & & 0.0322 & $* *$ & 0.0335 & & 0.0400 & * & 0.0279 & & 0.0339 & $* *$ & 0.0335 & & 0.0400 & * & 0.0329 & & 0.0388 & * \\
\hline Government & 1.3596 & & 2.6075 & & 1.5044 & & 3.5238 & & 1.2530 & & 2.6150 & & 1.5046 & & 3.5239 & & 1.4760 & & 3.6150 & \\
\hline $\begin{array}{l}\text { Expenditures } \\
\text { (\% GDP) }\end{array}$ & $\begin{array}{l}\mathbf{0 . 0 3 0 9} \\
1.6633\end{array}$ & $* * *$ & $\begin{array}{l}\mathbf{0 . 0 3 7 4} \\
3.3742\end{array}$ & * & $\begin{array}{l}\mathbf{0 . 0 3 3 2} \\
1.6918\end{array}$ & $* * *$ & $\begin{array}{l}\mathbf{0 . 0 3 3 2} \\
2.9008\end{array}$ & * & $\begin{array}{l}\mathbf{0 . 0 3 6 2} \\
1.8227\end{array}$ & *** & $\begin{array}{l}\mathbf{0 . 0 3 6 1} \\
3.0543\end{array}$ & * & $\begin{array}{l}\mathbf{0 . 0 3 3 2} \\
1.6919\end{array}$ & $* * *$ & $\begin{array}{l}\mathbf{0 . 0 3 3 2} \\
2.9005\end{array}$ & * & $\begin{array}{l}\mathbf{0 . 0 3 3 3} \\
1.6988\end{array}$ & $* * *$ & $\begin{array}{l}\mathbf{0 . 0 3 2 1} \\
2.8521\end{array}$ & * \\
\hline $\begin{array}{l}\text { Private Capital } \\
\text { Flows (\% GDP) }\end{array}$ & $\begin{array}{l}-\mathbf{0 . 0 0 0 9} \\
-0.2089\end{array}$ & & $\begin{array}{c}\mathbf{0 . 0 0 3 5} \\
1.6766\end{array}$ & $* * *$ & $\begin{array}{l}-\mathbf{- 0 . 0 0 1 0} \\
-0.2206\end{array}$ & & $\begin{array}{l}\mathbf{0 . 0 0 3 2} \\
1.4361\end{array}$ & & $\begin{array}{l}-\mathbf{- 0 . 0 0 2 1} \\
-0.4323\end{array}$ & & $\begin{array}{c}\mathbf{0 . 0 0 1 7} \\
0.7102\end{array}$ & & $\begin{array}{l}-\mathbf{- 0 . 0 0 1 0} \\
-0.2208\end{array}$ & & $\begin{array}{l}\mathbf{0 . 0 0 3 2} \\
1.4350\end{array}$ & & $\begin{array}{l}-\mathbf{- 0 . 0 0 1 9} \\
-0.4216\end{array}$ & & $\begin{array}{c}\mathbf{0 . 0 0 2 9} \\
1.3447\end{array}$ & \\
\hline $\begin{array}{l}\text { Overall Budget } \\
\text { (\% GDP) }\end{array}$ & -0.0095 & & -0.0347 & $* *$ & 0.0021 & & -0.0282 & $* * *$ & 0.0153 & & -0.0170 & & 0.0021 & & -0.0282 & *** & -0.0049 & & -0.0259 & **** \\
\hline & -0.2837 & & -1.9841 & & 0.0581 & & -1.9226 & & 0.4426 & & -0.9716 & & 0.0578 & & -1.9225 & & -0.1339 & & -1.8628 & \\
\hline GDP Growth Rate & -0.1116 & * & -0.0703 & * & -0.0787 & ** & -0.0388 & ** & -0.0804 & $* *$ & -0.0375 & $* * *$ & -0.0786 & ** & -0.0388 & ** & -0.0644 & & -0.0326 & ** \\
\hline $\begin{array}{l}\text { Total Trade } \\
\text { (\% GDP) }\end{array}$ & 0.3434 & & $\begin{array}{l}-2.9771 \\
\mathbf{0 . 2 2 2 7 4}\end{array}$ & & $\begin{array}{l}-2.0204 \\
0.2935\end{array}$ & & $\begin{array}{l}-2.3199 \\
\mathbf{0 . 0 0 0 1}\end{array}$ & & $\begin{array}{l}-2.1079 \\
0.2407\end{array}$ & & $\begin{array}{l}-1.8499 \\
\mathbf{0 . 0 2 9 3}\end{array}$ & & $\begin{array}{l}-2.0203 \\
0.2934\end{array}$ & & $\begin{array}{c}-2.3201 \\
-\mathbf{- 0 . 0 0 0 2}\end{array}$ & & $\begin{array}{l}-1.6464 \\
0.2844\end{array}$ & & $\begin{array}{l}-2.2549 \\
\mathbf{0 . 0 0 5 3}\end{array}$ & \\
\hline $\begin{array}{l}\text { Inflation Rate } \\
\text { (yearly) }\end{array}$ & -0.0071 & & -0.0028 & & -0.0080 & & -0.0032 & & -0.0041 & & -0.0005 & & -0.0080 & & -0.0032 & & -0.0078 & & -0.0041 & \\
\hline $\begin{array}{l}\text { Trade with } \\
\text { Epicenter }\end{array}$ & $\begin{array}{c}\mathbf{- 1 4 . 3 1 0 4} \\
-1.5595 \\
\end{array}$ & & $\begin{array}{l}-0.4089 \\
-\mathbf{5 . 6 7 6 0} \\
-1.6424 \\
\end{array}$ & & $\begin{array}{c}-0.6596 \\
-\mathbf{- 1 4 . 9 5 8 9} \\
-1.5459 \\
\end{array}$ & & $\begin{array}{c}-0.4396 \\
-9.3390 \\
-3.1005 \\
\end{array}$ & * & $\begin{array}{c}-0.3358 \\
-12.9166 \\
-1.4102 \\
\end{array}$ & & $\begin{array}{l}-0.0624 \\
-\mathbf{6 . 6 3 2 9} \\
-1.4336 \\
\end{array}$ & & $\begin{array}{c}-0.6597 \\
-\mathbf{1 4 . 9 5 9 9} \\
-1.5458 \\
\end{array}$ & & $\begin{array}{l}-0.4395 \\
-9.3437 \\
-3.1029 \\
\end{array}$ & * & $\begin{array}{c}-0.6464 \\
-17.5593 \\
-1.7832 \\
\end{array}$ & $* * *$ & $\begin{array}{c}-0.5722 \\
-\mathbf{- 1 1 . 3 9 3 4} \\
-4.4642 \\
\end{array}$ & $*$ \\
\hline (j. $\mathbf{R}^{\wedge} \mathbf{2}$ & 0.3181 & & 0.4674 & & 0.2417 & & 0.5014 & & 0.2781 & & 0.3298 & & 0.2417 & & 0.5015 & & 0.2222 & & 0.5522 & \\
\hline
\end{tabular}


Table 16. Regression Results Using a Fixed Time Period Effects Specification, Node Importance and Centrality Indices as the Network Indicators (Weekly Abnormal Stock Market Returns as the Dependent Variable)

\begin{tabular}{|c|c|c|c|c|c|c|c|c|c|c|}
\hline & $\begin{array}{c}\mathbf{1} / \\
\text { IV: World Trade } \\
\text { Share }\end{array}$ & & $\begin{array}{c}\mathbf{2 /} \\
\text { IV: Centrality } 1 \%\end{array}$ & & $\begin{array}{c}\text { 3/ } \\
\text { Threshold: } 0 \%\end{array}$ & & $\begin{array}{c}\text { 4/ } \\
\text { Threshold: } 1 \%\end{array}$ & & $\begin{array}{c}\mathbf{5} / \\
\text { Threshold: } 2 \%\end{array}$ & \\
\hline Country $i$ importance & $\begin{array}{c}\mathbf{3 . 6 6 9 1} \\
2.9441\end{array}$ & * & $\begin{array}{l}\mathbf{1 . 6 8 4 2} \\
1.0503\end{array}$ & & & & & & & \\
\hline Country $i$ Centrality & & & & & $\begin{array}{l}\mathbf{0 . 0 0 6 4} \\
2.07718\end{array}$ & ** & $\begin{array}{l}\mathbf{0 . 0 0 1 7} \\
1.04702\end{array}$ & & $\begin{array}{l}\mathbf{0 . 0 0 2 4} \\
1.53782\end{array}$ & \\
\hline Constant & $\begin{array}{l}\mathbf{- 1 . 2 1 1 1} \\
-5.1765\end{array}$ & * & $\begin{array}{l}\mathbf{- 1 . 0 4 3 5} \\
-5.3488\end{array}$ & * & $\begin{array}{c}\mathbf{- 1 . 5 1 9 1} \\
-4.5087\end{array}$ & * & $\begin{array}{l}\mathbf{- 1 . 0 4 3 2} \\
-5.3472\end{array}$ & * & $\begin{array}{l}\mathbf{- 1 . 0 7 3 9} \\
-5.6257\end{array}$ & * \\
\hline Dummy Venezuela & $\begin{array}{l}\mathbf{0 . 7 7 2 8} \\
5.6581\end{array}$ & * & $\begin{array}{l}\mathbf{0 . 7 5 7 3} \\
5.6346\end{array}$ & * & $\begin{array}{l}\mathbf{0 . 7 6 3 3} \\
5.7709\end{array}$ & * & $\begin{array}{l}\mathbf{0 . 7 5 7 3} \\
5.6340\end{array}$ & * & $\begin{array}{l}\mathbf{0 . 7 5 7 6} \\
5.7608\end{array}$ & * \\
\hline Dummy Thailand & $\begin{array}{l}\mathbf{0 . 2 9 0 5} \\
2.1183\end{array}$ & $* *$ & $\begin{array}{l}\mathbf{0 . 2 8 1 2} \\
2.1837\end{array}$ & $* *$ & $\begin{array}{l}\mathbf{0 . 2 6 5 3} \\
1.9764\end{array}$ & $* * *$ & $\begin{array}{l}\mathbf{0 . 2 8 1 2} \\
2.1837\end{array}$ & ** & $\begin{array}{l}\mathbf{0 . 2 8 2 3} \\
2.1784\end{array}$ & $* *$ \\
\hline Dummy Russia & $\begin{array}{c}\mathbf{0 . 2 6 4 0} \\
1.8777\end{array}$ & $* * *$ & $\begin{array}{c}\mathbf{0 . 2 4 8 0} \\
1.8811\end{array}$ & $* * *$ & $\begin{array}{c}\mathbf{0 . 2 3 4 5} \\
1.7125\end{array}$ & $* * *$ & $\begin{array}{l}\mathbf{0 . 2 4 8 0} \\
1.8813\end{array}$ & $* * *$ & $\begin{array}{l}\mathbf{0 . 2 4 5 5} \\
1.8396\end{array}$ & $* * *$ \\
\hline Dummy Argentina & $\begin{array}{l}\mathbf{0 . 2 5 7 1} \\
1.7251\end{array}$ & $* * *$ & $\begin{array}{l}\mathbf{0 . 2 4 8 7} \\
1.7080\end{array}$ & $* * *$ & $\begin{array}{c}\mathbf{0 . 2 6 9 3} \\
1.8051\end{array}$ & $* * *$ & $\begin{array}{l}\mathbf{0 . 2 4 8 6} \\
1.7075\end{array}$ & $* * *$ & $\begin{array}{l}\mathbf{0 . 2 5 5 2} \\
1.7648\end{array}$ & $* * *$ \\
\hline Bank Reserves to Assets ratio & $\begin{array}{c}\mathbf{- 0 . 0 0 0 3} \\
-0.0257\end{array}$ & & $\begin{array}{c}-\mathbf{- 0 . 0 0 2 6} \\
-0.2367\end{array}$ & & $\begin{array}{c}\mathbf{0 . 0 0 0 1} \\
0.0109\end{array}$ & & $\begin{array}{l}\mathbf{- 0 . 0 0 2 6} \\
-0.2370\end{array}$ & & $\begin{array}{c}\mathbf{- 0 . 0 0 3 0} \\
-0.2770\end{array}$ & \\
\hline Current Account (\% GDP) & $\begin{array}{l}\mathbf{0 . 0 2 9 5} \\
2.6509\end{array}$ & * & $\begin{array}{l}\mathbf{0 . 0 3 1 2} \\
2.7183\end{array}$ & * & $\begin{array}{c}\mathbf{0 . 0 2 8 3} \\
2.4129\end{array}$ & $* *$ & $\begin{array}{l}\mathbf{0 . 0 3 1 2} \\
2.7185\end{array}$ & * & $\begin{array}{l}\mathbf{0 . 0 3 1 3} \\
2.7995\end{array}$ & * \\
\hline Government Expenditures (\% GDP) & $\begin{array}{l}\mathbf{0 . 0 3 0 9} \\
3.1121\end{array}$ & * & $\begin{array}{l}\mathbf{0 . 0 3 0 6} \\
3.1429\end{array}$ & * & $\begin{array}{l}\mathbf{0 . 0 3 2 1} \\
3.2972\end{array}$ & * & $\begin{array}{l}\mathbf{0 . 0 3 0 6} \\
3.1431\end{array}$ & * & $\begin{array}{l}\mathbf{0 . 0 3 0 9} \\
3.1407\end{array}$ & * \\
\hline Private Capital Flows (\% GDP) & $\begin{array}{l}\mathbf{0 . 0 0 1 4} \\
0.8194\end{array}$ & & $\begin{array}{l}\mathbf{0 . 0 0 0 5} \\
0.2525\end{array}$ & & $\begin{array}{c}\mathbf{- 0 . 0 0 0 1} \\
-0.0746\end{array}$ & & $\begin{array}{l}\mathbf{0 . 0 0 0 5} \\
0.2521\end{array}$ & & $\begin{array}{l}\mathbf{0 . 0 0 0 6} \\
0.3062\end{array}$ & \\
\hline Overall Budget (\% GDP) & $\begin{array}{l}-\mathbf{0 . 0 4 4 2} \\
-2.6795\end{array}$ & * & $\begin{array}{l}\mathbf{- 0 . 0 3 7 5} \\
-2.2766\end{array}$ & $* *$ & $\begin{array}{c}\mathbf{- 0 . 0 2 9 4} \\
-1.7687\end{array}$ & $* * *$ & $\begin{array}{c}\mathbf{- 0 . 0 3 7 5} \\
-2.2764\end{array}$ & $* *$ & $\begin{array}{l}\mathbf{- 0 . 0 3 8 8} \\
-2.3871\end{array}$ & $* *$ \\
\hline GDP Growth Rate & $\begin{array}{l}-\mathbf{0 . 0 7 3 6} \\
-3.0157\end{array}$ & * & $\begin{array}{l}-\mathbf{- 0 . 0 8 0 0} \\
-3.1902\end{array}$ & * & $\begin{array}{c}-\mathbf{0 . 0 7 3 2} \\
-2.8514\end{array}$ & * & $\begin{array}{c}-\mathbf{- 0 . 0 8 0 0} \\
-3.1909\end{array}$ & * & $\begin{array}{l}-\mathbf{- 0 . 0 7 7 6} \\
-3.0945\end{array}$ & * \\
\hline Total Trade (\% GDP) & $\begin{array}{c}\mathbf{0 . 3 2 2 4} \\
1.5649\end{array}$ & & $\begin{array}{l}\mathbf{0 . 2 4 4 1} \\
1.2088\end{array}$ & & $\begin{array}{c}\mathbf{0 . 2 2 7 7} \\
1.1613\end{array}$ & & $\begin{array}{l}\mathbf{0 . 2 4 4 0} \\
1.2083\end{array}$ & & $\begin{array}{l}\mathbf{0 . 2 7 3 2} \\
1.3278\end{array}$ & \\
\hline Inflation Rate (yearly) & $\begin{array}{c}\mathbf{0 . 0 0 0 0 4} \\
0.0067\end{array}$ & & $\begin{array}{c}\mathbf{- 0 . 0 0 1 0} \\
-0.1646\end{array}$ & & $\begin{array}{c}\mathbf{0 . 0 0 0 0} \\
0.0017\end{array}$ & & $\begin{array}{c}-\mathbf{- 0 . 0 0 1 0} \\
-0.1649\end{array}$ & & $\begin{array}{l}-\mathbf{- 0 . 0 0 0 7} \\
-0.1071\end{array}$ & \\
\hline Trade with Epicenter & $\begin{array}{l}\mathbf{- 5 . 0 6 3 4} \\
-1.2478 \\
\end{array}$ & & $\begin{array}{l}\mathbf{- 5 . 7 4 3 3} \\
-1.3404 \\
\end{array}$ & & $\begin{array}{l}\mathbf{- 4 . 8 0 1 8} \\
-1.1025 \\
\end{array}$ & & $\begin{array}{l}-\mathbf{5 . 7 4 4 8} \\
-1.3407 \\
\end{array}$ & & $\begin{array}{l}\mathbf{- 5 . 6 1 1 6} \\
-1.3145 \\
\end{array}$ & \\
\hline $\operatorname{adj} . R^{\wedge} 2$ & 0.4342 & & 0.4777 & & 0.4426 & & 0.4778 & & 0.4646 & \\
\hline
\end{tabular}

IV: Intrinsic Value. $\mathrm{t}$ - statistics reported in italics. 


\section{Appendix}

\begin{tabular}{|c|c|c|}
\hline \multicolumn{3}{|c|}{ Control Variables } \\
\hline As referred in the paper & As referred in the WDI database and/or computation & WDI code \\
\hline Bank reserves to assets ratio & Bank liquid reserves to bank assets ratio & FD.RES.LIQU.AS.ZS \\
\hline $\begin{array}{l}\text { Current account balanceas } \\
\text { percentage of GDP }\end{array}$ & External balance on goods and services (\% of GDP) * & NE.RSB.GNFS.ZS \\
\hline $\begin{array}{l}\text { Government Expenditures as } \\
\text { percentage of GDP }\end{array}$ & $\begin{array}{l}\text { General government final consumption expenditure (\% of } \\
\qquad \text { GDP) }\end{array}$ & NE.CON.GOVT.ZS \\
\hline $\begin{array}{l}\text { Private Capital Flows as percentage } \\
\text { of GDP }\end{array}$ & Gross private capital flows (\% of GDP) & BG.KAC.FNEI.GD.ZS \\
\hline $\begin{array}{l}\text { Government Budget Balance as } \\
\text { percentage of GDP }\end{array}$ & Overall budget balance, including grants (\% of GDP) & GB.BAL.OVRL.GD.ZS \\
\hline GDP growth rate & GDP growth (annual \%) & NY.GDP.MKTP.KD.ZG \\
\hline Total trade as percentage of GDP & Trade (\% of GDP) & NE.TRD.GNFS.ZS \\
\hline Yearly Inflation Rate & Calculated using Consumer price index (1995 = 100) & FP.CPI.TOTL \\
\hline $\begin{array}{l}\text { Trade with Epicenter (calculated } \\
\text { using the NBER-UN world trade } \\
\text { database) }\end{array}$ & $\begin{array}{c}\text { Exports of country } i \text { to Epicenter plus Imports of country } \\
i \text { from Epicenter over the Total Exports plus Total } \\
\text { Imports of country } i \text {. }\end{array}$ & - \\
\hline
\end{tabular}

\begin{tabular}{ccc}
\hline \multicolumn{3}{c}{ Countries Included in the Analysis } \\
\hline \hline Argentina & Hungary & Poland \\
Australia & India & Portugal \\
Austria & Indonesia & Russia \\
Belgium & Israel & Singapore \\
Brazil & Italy & Spain \\
Canada & Japan & Sweden \\
Chile & Korea & Switzerland \\
China & Luxemburg & Thailand \\
Czech Republic & Malaysia & UK \\
Denmark & Mexico & US \\
Finland & Netherlands & Venezuela \\
France & New Zealand & \\
Germany & Norway & \\
Greece & Peru & \\
Hong Kong & Phillippines & \\
\hline \hline
\end{tabular}

Because of data availability, italicized countries are not present in all regressions.

\begin{tabular}{lc}
\hline \multicolumn{2}{c}{ Number of Crossections included in Regressions } \\
\hline \hline Table 6. & 34 \\
Table 9. & 34 \\
Table 10. & 35 (A) and 35 (B) \\
Table 11. & Panel 1. 38, Panel 2. 39 (A) and 40 (B) \\
Table 12. & Panel 1. 34, Panel 2. 35 (A) and 35 (B) \\
Table 13. & Panel 1. 38, Panel 2. 39 (A) and 40 (B) \\
Table 15. & 38 \\
Table 16. & 34 \\
\hline \hline
\end{tabular}




\section{Data Descriptive Statistics}

\begin{tabular}{|c|c|c|c|c|c|}
\hline \multicolumn{6}{|c|}{$\begin{array}{c}\text { Network Indicator Statistics } \\
\text { (Trade Based Dependency: Exports of Country } i \text { to Country } j \text { out of total exports of Country i) }\end{array}$} \\
\hline & $\begin{array}{l}\text { Epicenter Importance Index } \\
\text { (IV: World Trade Share) }\end{array}$ & $\begin{array}{l}\text { Country } i \text { Importance Index } \\
\text { (IV: World Trade Share) }\end{array}$ & $\begin{array}{c}\text { Epicenter Importance Index } \\
\text { (IV: Centrality } 1 \% \\
\text { threshold) } \\
\end{array}$ & $\begin{array}{l}\text { Country } i \text { Importance Index } \\
\text { (IV: Centrality } 1 \% \text { threshold) }\end{array}$ & $\begin{array}{l}\text { Epicenter Centrality } \\
\text { ( } 0 \% \text { threshold })\end{array}$ \\
\hline Mean & 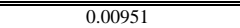 & 0.02059 & $\begin{array}{ll}0.01702 \\
\end{array}$ & 0.02874 & $\begin{array}{l}64.82760 \\
\end{array}$ \\
\hline Maximum & 0.01691 & 0.16188 & 0.03048 & 0.09391 & 83.90800 \\
\hline Minimum & 0.00296 & 0.00075 & 0.00403 & 0.00000 & 45.97700 \\
\hline \multirow[t]{2}{*}{ Std. Dev. } & 0.00533 & 0.02754 & 0.01112 & 0.02580 & 12.99970 \\
\hline & $\begin{array}{c}\text { Country i Centrality } \\
\text { (0\% threshold) }\end{array}$ & $\begin{array}{c}\text { Epicenter Centrality } \\
(1 \% \text { threshold })\end{array}$ & $\begin{array}{c}\text { Country i Centrality } \\
(1 \% \text { threshold) }\end{array}$ & $\begin{array}{c}\text { Epicenter Centrality } \\
(2 \% \text { threshold })\end{array}$ & $\begin{array}{c}\text { Country i Centrality } \\
\text { (2\% threshold) }\end{array}$ \\
\hline Mean & 73.59388 & 17.01160 & 28.710 & (10.920 & 19.576 \\
\hline Maximum & 99.42500 & 30.46000 & 93.678 & 22.989 & 88.506 \\
\hline Minimum & 0.00000 & 4.02300 & 0.000 & 2.299 & 0.000 \\
\hline \multirow[t]{2}{*}{ Std. Dev. } & 16.47745 & 11.11311 & 25.7661 & 8.1622 & 22.1771 \\
\hline & $\begin{array}{c}\text { Maximum Flow Epicenter to } \\
\text { Country i } \\
(0 \% \text { threshold })\end{array}$ & $\begin{array}{c}\text { Maximum Flow Epicenter to } \\
\text { Country i } \\
(0.5 \% \text { threshold })\end{array}$ & $\begin{array}{c}\text { Maximum Flow Epicenter } \\
\text { to Country i } \\
\text { ( } 1 \% \text { threshold }) \\
\end{array}$ & $\begin{array}{c}\text { Maximum Flow Epicenter to } \\
\text { Country i } \\
\text { ( } 2 \% \text { threshold }) \\
\end{array}$ & \\
\hline Mean & 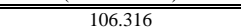 & 20.716 & 12.836 & ב 4.747 & \\
\hline Maximum & 146.000 & 40.000 & 24.000 & 13.000 & \\
\hline Minimum & 0.000 & 0.000 & 0.000 & 0.000 & \\
\hline Std. Dev. & 26.0609 & 8.7785 & 5.5689 & 3.6281 & \\
\hline \multicolumn{6}{|c|}{ 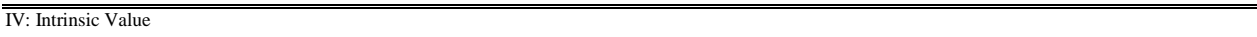 } \\
\hline \multicolumn{6}{|c|}{$\begin{array}{c}\text { Network Indicator Statistics } \\
\text { (GDP Based Dependency: Exports of Country i to Country j out of Country i's GDP) }\end{array}$} \\
\hline & $\begin{array}{l}\text { Epicenter Importance Index } \\
\text { (IV: World Trade Share) }\end{array}$ & $\begin{array}{l}\text { Country } i \text { Importance Index } \\
\text { (IV: World Trade Share) }\end{array}$ & $\begin{array}{l}\text { Epicenter Importance Index } \\
\text { (IV: Centrality 1\% } \\
\text { threshold) }\end{array}$ & $\begin{array}{l}\text { Country } i \text { Importance Index } \\
\text { (IV: Centrality } 1 \% \text { threshold) }\end{array}$ & $\begin{array}{l}\text { Epicenter Centrality } \\
(0 \% \text { threshold })\end{array}$ \\
\hline Mean & 0.00950 & 0.02057 & 0.00931 & 0.01792 & 6464.36800 \\
\hline Maximum & 0.01690 & 0.16176 & 0.02012 & 0.07878 & 82.75900 \\
\hline Minimum & 0.00296 & 0.00075 & 0.00287 & 0.00000 & 45.97700 \\
\hline \multirow[t]{2}{*}{ Std. Dev. } & 0.00532 & 0.02752 & 0.00716 & 0.01925 & 12.65624 \\
\hline & $\begin{array}{c}\text { Country i Centrality } \\
\text { (0\% threshold) }\end{array}$ & $\begin{array}{c}\text { Epicenter Centrality } \\
\text { (1\% threshold) }\end{array}$ & $\begin{array}{c}\text { Country i Centrality } \\
\text { (1\% threshold) }\end{array}$ & $\begin{array}{c}\text { Epicenter Centrality } \\
(2 \% \text { threshold })\end{array}$ & $\begin{array}{c}\text { Country i Centrality } \\
\text { (2\% threshold) }\end{array}$ \\
\hline Mean & 72.80972 & 9.31040 & 17.872 & 5.747 & 11.101 \\
\hline Maximum & 97.12600 & 20.11500 & 78.736 & 15.517 & 70.690 \\
\hline Minimum & 0.00000 & 2.87400 & 0.000 & 1.149 & 0.000 \\
\hline Std. Dev. & 15.95887 & 7.16075 & 19.235 & 5.620 & 14.336 \\
\hline
\end{tabular}

Dependent Variable and Macroeconomic Control Variables

\begin{tabular}{|c|c|c|c|c|c|}
\hline & $\begin{array}{l}\text { Abnormal Stock Market } \\
\text { Return } \\
\text { (Deviation from average } \\
\text { before 1994) }\end{array}$ & $\begin{array}{l}\text { Abnormal Stock Market Return } \\
\text { (Deviation from overall } \\
\text { average before } 1992-2000 \text { ) }\end{array}$ & Total Trade to GDP Ratio & Yearly Inflation & $\begin{array}{c}\text { Bank Reserves to Assets } \\
\text { Ratio }\end{array}$ \\
\hline Mean & $\begin{array}{ll}-0.42383 \\
\end{array}$ & - & $\begin{array}{l}73.03769 \\
\end{array}$ & (13.47255 & - 6.86191 \\
\hline Maximum & 2.12612 & 2.34622 & 287.40550 & 874.62190 & 34.13177 \\
\hline Minimum & -7.66728 & -7.53382 & 15.92322 & -5.20943 & 0.02018 \\
\hline Std. Dev. & 1.27660 & 1.14775 & 52.00246 & 62.93572 & 7.69720 \\
\hline
\end{tabular}

\begin{tabular}{|c|c|c|c|c|c|c|}
\hline & $\begin{array}{l}\text { Current Account } \\
\text { to GDP Ratio }\end{array}$ & $\begin{array}{l}\text { Government Consumption to } \\
\text { GDP Ratio }\end{array}$ & $\begin{array}{l}\text { Private Capital Inflows } \\
\text { to GDP Ratio }\end{array}$ & $\begin{array}{l}\text { Government Budget } \\
\text { to GDP Ratio }\end{array}$ & GDP Growht Rate & Trade with Epicenter \\
\hline$\overline{~ M e a n ~}$ & 0.6695 & 16.5772 & 21.6734 & -1.7916 & 3.8807 & 0.0109 \\
\hline Maximum & 22.1613 & 29.4407 & 179.1754 & 16.0776 & 13.5000 & 0.1031 \\
\hline Minimum & -16.1205 & 5.0128 & 2.5377 & -14.9732 & -12.5698 & 0.0000 \\
\hline Std. Dev. & 5.6517 & 5.5678 & 22.7116 & 4.2842 & 3.2907 & 0.0178 \\
\hline
\end{tabular}

